\title{
INFLUENCE OF CLIMATE AND DOLOMITE COMPOSITION ON DEDOLOMITIZATION: INSIGHTS FROM A MULTI-PROXY STUDY IN THE CENTRAL OMAN MOUNTAINS
}

\author{
VEERLE VANDEGINSTE AND CÉDRIC M. JOHN \\ Department of Earth Science and Engineering, Imperial College, London, SW7 2BP, London, U.K. \\ e-mail:v.vandeginste@imperial.ac.uk
}

\begin{abstract}
Dedolomitization is an important diagenetic process that can yield information on the history of paleo-fluids in a given aquifer or outcrop, and by extension it offers a window into past hydrologic conditions. Dedolomitization is also relevant economically as it can alter the porosity and permeability of carbonates, thus affecting reservoir quality. Despite considerable research, the process of dedolomitization is still not entirely understood. Here, new findings from the central Oman Mountains highlight the importance of dolomite chemistry and fluctuating climate on dedolomitization. Petrographic, mineralogical, and geochemical data from both altered and pristine dolomite hosted in Jurassic carbonate rocks from the Sahtan Group and outcropping at Wadi Mistal in the Jebel Akhdar tectonic window reveal two dolomite bodies with different characteristics, stratabound and fault-related dolostone. The (ferroan) dolomite crystals are larger in the fault-related dolostone, whereas the (non-ferroan) dolomite crystals are smaller in the stratabound dolostone. Petrography reveals a complex suite of alteration textures, including pristine dolomite, recrystallized dolomite, and calcitized dolomite (dedolomite). Iron oxides are present pervasively in the altered rocks, and different alteration textures co-occur in the same sample. Relative to unaltered dolomite in this outcrop, the recrystallized dolomite is characterized by similar positive carbon isotope values but less negative oxygen isotope values, and the calcitized dolomite is characterized by even less negative oxygen isotope values and more negative carbon isotope values. Based on field data and petrography, two phases of alteration are evident, an earlier dedolomitization event affecting the stratabound dolomite only, and a more pervasive Pleistocene-Holocene alteration phase associated with surface weathering that affected both the fault-related dolomite and to a lesser extent the stratabound dolomite. Stable isotope results further suggest that the more recent subaerial weathering phase happened under two alternating climate regimes: dedolomitization was triggered by meteoric fluids that interacted with soil-related carbon during humid climatic period(s), whereas recrystallization of ferroan fault-related dolomite happened during more arid climatic period(s) with less developed soils and lower fluid-rock interaction. These results suggest that weathering of ferroan fault-related dolomite can lead to formation of goethite and recrystallized, non-stoichiometric dolomite (with a reset stable oxygen isotope signature), and sometimes to dedolomitization.
\end{abstract}

\section{INTRODUCTION}

Von Morlot (1847) introduced the term "dedolomitization" to refer to the process of dolomite replacement by calcite via the interaction with fluids with a high $\mathrm{Ca}^{2+} / \mathrm{Mg}^{2+}$ ratio, i.e., calcitization of dolomite. The product of dedolomitization is commonly referred to as "dedolomite" (Back et al. 1983). In addition, the process of dedolomitization can lead to the formation of calcitic cements filling both veins and the pore space of the host rock (Back et al. 1983).

Dedolomitization is a fundamental and understudied process that has far-ranging implications for water quality and reservoir-rock properties (Cantrell et al. 2007), and that can help unravel the evolution of fluid flow in a given region (Back et al. 1983). For instance, dedolomitization can be a major factor controlling the evolution of the chemical composition of basinal fluids, groundwaters, or surface waters (Back et al. 1983; Deike 1990). Because dedolomitization commonly involves interaction with meteoric fluid, dedolomite chemistry can yield important information on the climate and hydrology of a region. Dedolomitization also can impact the petrophysical properties of dolomite, thus affecting reservoir quality by changing porosity and permeability (Al-Hashimi and Hemingway 1973; Ayora et al. 1998). To better assess the global impact of dedolomitization, regional studies exploring fundamental controls on dedolomitization are needed.

Several studies have been devoted to understanding the process of dedolomitization. Nonetheless, the controlling mechanisms of dedolomitization are not completely understood, and different dedolomitization modes, different diagenetic environments, and different mechanisms and fluid types responsible for dedolomitization have been suggested. Dedolomitization has been reported in a range of diagenetic environments. Most studies propose that dedolomitization is a near-surface process, either recent or related to a paleosurface (e.g., Goldberg 1967; Braun and Friedman 1970; Magaritz and Kafri 1981; Kenny 1992; SanzRubio et al. 2001), consistent with the findings of De Groot (1967). The latter author found that (1) a high fluid flow rate to remove $\mathrm{Mg}^{2+}$ and keep the $\mathrm{Ca}^{2+} / \mathrm{Mg}^{2+}$ ratio elevated, (2) a low $\mathrm{CO}_{2}$ partial pressure, similar to that of the atmosphere, and (3) a temperature below $50^{\circ} \mathrm{C}$ are needed for effective dedolomitization. However, Budai et al. (1984) suggested that some dedolomitization may be of deep burial origin on the basis of 
isotopic evidence and the presence of replacement calcite intergrown within stylolite seams. Dedolomitization has been explained mostly by one of the two following models: (1) interaction with calcium-sulfate-rich fluids, commonly related to dissolution of gypsum or anhydrite (Von Morlot 1847; Shearman et al. 1961; Evamy 1963; Goldberg 1967; Folkman 1969; Bischoff et al. 1994), and (2) oxidation of ferrous iron in dolomite under subaerial conditions (Katz 1971; Al-Hashimi and Hemingway 1973; Frank 1981). These two models are thought to involve a one-step dedolomitization process, i.e., pseudomorphic replacement of dolomite by calcite, whereby dolomite dissolves simultaneously with precipitation of calcite (Al-Hashimi and Hemingway 1973; James et al. 1993). A third model explains dedolomitization as a two-step process, involving complete dissolution of metastable dolomite (for example dissolution of Ca-rich dolomite by meteoric groundwater) followed by precipitation of cavity-filling calcite during the same overall process (Kenny 1992) or from a different solution at a different time (Jones et al. 1989; James et al. 1993).

This paper focuses on alteration of dolomite and the process of dedolomitization at Wadi Mistal (Oman Mountains) by investigating alteration textures and elemental and stable isotope composition of dolomite, calcitized dolomite, altered dolomite (including iron hydroxides), and calcite cements, all collected from the same Jurassic $(8 \mathrm{~m} \times 12 \mathrm{~m}$ scale) outcrop. The paper presents a new case study for dedolomitization and aims at improving fundamental understanding of this process. As will be shown here, the alteration textures of the dolomite in the outcrop studied in Oman are peculiar and the alteration product is not always dedolomite. As such, Wadi Mistal offers a unique opportunity to understand what controls the abundance of dedolomite in a single outcrop. The goal of this study is to provide more insight into the alteration processes of dolomite by exploring how controlling factors affect alteration textures. The results of this study clearly illustrate that certain dolomite properties determine its susceptibility to alteration and that climate can control the type of alteration process.

\section{Geological Setting}

The study area of Wadi Mistal is situated in the Jebel Akhdar tectonic window of the central part of the Oman Mountains (Figs. 1, 2). The Oman Mountains are an arcuate mountain belt $40 \mathrm{~km}$ to $150 \mathrm{~km}$ wide by $700 \mathrm{~km}$ long extending from the Musandam Peninsula in the north to the Batain coast in the southeast. The Oman Mountains developed as part of the Alpine Orogeny in response to northeast-directed subduction of Arabia below the Eurasian Plate (Hilgers et al. 2006). Jebel Akdar is one of the regional tectonic windows opening through the oceanic allochthon of the Hawasina volcano-sedimentary nappe complex and the overlying Semail ophiolite (Poupeau et al. 1998). The Hawasina Nappes are remnants of the distal part of the south Neotethyan continental margin, whereas the Arabian Platform corresponds to its shallow-water (neritic) proximal part (Searle and Graham 1982; Béchennec et al. 1988). The lowgrade greenschist-facies Late Proterozoic rocks in the Jebel Akhdar dome are unconformably overlain by weakly metamorphosed middle Permian to Cenomanian carbonates. The carbonates, forming a succession $2.5 \mathrm{~km}$ thick, were deposited on the subsiding southern passive margin of the Tethyan ocean (Hanna 1990; Rabu et al. 1990; Mann et al. 1990; Pratt and Smewing 1993; Masse et al. 1997, 1998; Hillgärtner et al. 2003). This succession is known as the Hajar Supergroup and includes, from bottom to top, middle-Late Permian fusulinid limestone (Saiq Formation), Triassic calc-dolomites (Mahil Formation), Jurassic limestone and siliciclastic red beds (Sahtan Group), and lower Cretaceous-Cenomanian limestone (Kahmah and Wasia Groups; Saddiqi et al. 2006). The Jurassic-Cretaceous limestone is disconformably topped by the Turonian-Santonian clastic marls and olistostromes (Muti Formation or lower Aruna Group), which correspond to foredeep deposits
(Robertson 1987; Rabu et al. 1990) and generally form the footwall of the Tethyan nappes. Post-nappe, shallow-water sediments were deposited over the ophiolite front in the foredeep as early as in the late Maastrichtian and continued during the Tertiary (Saddiqi et al. 2006). The host-rocks of the studied dolomite body in Wadi Mistal are Jurassic in age and belong to the Sahtan Group (Fig. 2).

\section{METHODOLOGY}

A total of 34 samples were collected in the outcrop in Wadi Mistal (Fig. 3): 11 samples come from the brick-red, fault-related dolostone body ("Fault-Related Dolostone," hereafter FRD), 20 samples come from the host-rock, which is composed of bluish gray limestone and brown, stratabound dolomitized limestone and dolostone ("StrataBound Dolostone," hereafter SBD), and three samples capture the contact between the brick-red dolostone and the Jurassic host-rock limestone. All samples were analyzed by microscopic, cathodoluminescence (CL) microscopic, X-ray diffraction (XRD), elemental geochemical, and stable isotope techniques. A subset of seven samples was analyzed further with the scanning electron microscope to look at high-resolution altered dolomite features.

Rock slabs were finely polished and etched using $1 \mathrm{M} \mathrm{HCl}$. Rocks slabs and half of each thin-section were stained with Alizarin Red S and potassium ferricyanide to distinguish calcite and dolomite and their ferroan equivalents following a procedure modified from Dickson (1966). Transmitted-light microscopy was carried out on 42 thin-sections using a Zeiss Axioskop 40 microscope. For cathodoluminescence (CL) petrography, a CITL Cathodoluminescence Mk5-2 stage mounted on a Nikon Eclipse 50i microscope was used with an attached Nikon DS-Filc digital camera. Operating conditions were about $270 \mu \mathrm{A}$ and $14 \mathrm{kV}$. The same 42 thin-sections used for normal microscopy were also used for CL microscopy; luminescence color descriptions are based on unstained thin-section halves.

Small stubs of rock samples were coated with Au-Pd and studied under a LEO 1455 VP scanning electron microscope (SEM). The SEM was operated at EHT of $20 \mathrm{kV}$.

One to two grams of bulk rock samples were prepared for X-ray diffraction (XRD) by sawing a small piece of sample, cleaning it with distilled water, drying it overnight, and then crushing it into a powder using an agate mortar and pestle. The samples were spiked with halite to serve as an internal standard. The analyses were performed on a Philips PW 1830 diffractometer system using $\mathrm{CuK} \alpha$ radiation at $45 \mathrm{kV}$ and $40 \mathrm{~mA}$. The XRD system is fitted with a PW 1820 goniometer and a graphite monochromator. The powders were scanned over a sampling range of 2.5 to $70^{\circ} 2 \theta$ with a sampling interval of $0.01^{\circ} 2 \theta$ per step and a scan speed of 2 seconds per step. Artificial mixtures of calcite and dolomite with internal halite standard were run to calibrate the XRD system and quantify the abundance of calcite and dolomite present in the samples. Maximum error of calculated percentages at the $95 \%$ confidence interval is about $2 \%$ where there is up to $10 \%$ of a component present and about $7 \%$ for higher percentages of a component. Stoichiometry of dolomite is determined using the equation of Lumsden (1979), after correction for the shift in $d_{104}$ peak associated with the iron concentration in the ferroan dolomite.

Bulk powders for elemental analysis were prepared in a manner similar to XRD samples. An aliquot of $250 \mathrm{mg}$ of bulk carbonate powder was dissolved in $50 \mathrm{ml}$ of a $5 \% \mathrm{HNO}_{3}$ solution. For this process, the acid is added to the carbonate powder in four steps, two of $5 \mathrm{ml}$ and two of $10 \mathrm{ml}$. The solutions then are heated to about $80^{\circ} \mathrm{C}$ for one hour. Subsequently, the solutions are filtered and acid is added until a volume of $50 \mathrm{ml}$ is obtained. Element concentrations ( $\mathrm{Ca}, \mathrm{Mg}, \mathrm{Mn}, \mathrm{Fe}, \mathrm{Na}, \mathrm{Sr}, \mathrm{K}$, $\mathrm{Al})$ are measured in these solutions by ICP-AES. Analytical precision at the $95 \%$ confidence level determined on replicate analyses is about $15 \%$ 


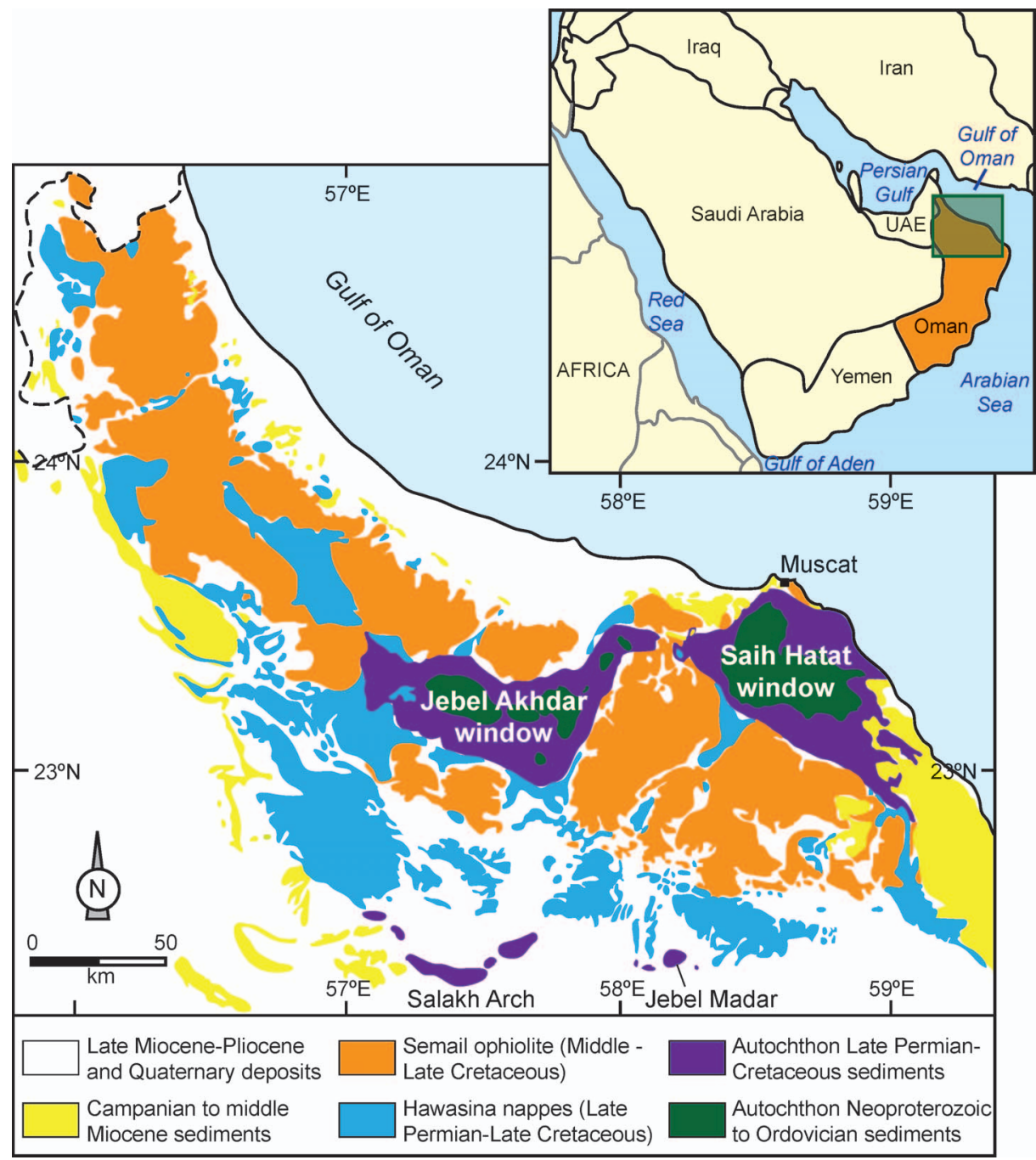

Fig. 1.-Geological map of northern Oman (after Le Métour et al. 1993). Inset figure shows part of the Middle East, locating Oman (indicated in orange), with the green box delineating the Jebel Akhdar area presented on the geological map. for $\mathrm{Ca}, \mathrm{Mg}, \mathrm{Al}, \mathrm{Na}$, and $\mathrm{Sr}$, and $10 \%$ for $\mathrm{Fe}$ and $\mathrm{Mn}$. A powdered dolomite standard (GBW07114) was used for internal calibration of the method, and prepared in the same way as the samples.

In samples where the dolomite fraction represented $40 \%$ or more of the total carbonate, the dolomite fraction was separated and its elemental composition was measured. For this separation, calcite was dissolved from the bulk powders by reacting the sample with a buffered solution composed of $5 \%$ acetic acid with ammonium acetate added to obtain a $\mathrm{pH}$ of 5. A 1 or 2 gram aliquot of bulk powder was shaken for two hours in 100 or $200 \mathrm{ml}$, respectively, of this solution. The solution was then filtered and the filter let to dry overnight in an oven set at $50^{\circ} \mathrm{C}$. The residue (representing the dolomite fraction and non-carbonate) was collected. Part of the residue was used for XRD to verify that there was no calcite left in the sample. Subsequently, the residue was processed for elemental composition as explained above for the bulk carbonate samples.

Stable carbon and oxygen isotope analyses were carried out on carbonate powders that were drilled with a dental drill. This microsampling approach targeted specific diagenetic phases, namely pristine dolomite, altered dolomite, and dedolomite. However, three samples of altered FRD and all SBD samples were analyzed for stable isotopes by taking the separated dolomite fractions prepared for elemental analysis. In addition, tests of dolomite and goethite mixtures were carried out to verify that no goethite dissolved in acid or affected the stable isotopic results in any other way. Tests were also performed on the dolomite standard (GBW07114), which was analyzed both as bulk and as extracted dolomite fraction using the chemical procedure explained above, to verify that this chemical treatment has no effect on the stable isotope signature of the dolomite. The samples (100 to $150 \mu \mathrm{g}$ ) were reacted with phosphoric acid in a Thermo Scientific automated Kiel IV carbonate device and the resulting $\mathrm{CO}_{2}$ gas was analyzed on a MAT253 mass spectrometer. All values are reported in per mil relative to the Vienna Pee Dee Belemnite (VPDB). Drifts in the values were corrected using the National Bureau of Standards 19 (NBS19, $\delta{ }^{13} \mathrm{C}$ value of $+1.95 \%$ and a $\delta^{18} \mathrm{O}$ value of $-2.20 \%$ ) and an internal laboratory standard (Imperial College Carrara marble, ICCM). The oxygen isotope composition of dolomite was corrected for acid fractionation using the fractionation factors given by Rosenbaum and Sheppard (1986). Reproducibility was checked by replicate analysis of laboratory standards and NBS19 and was better than $0.04 \%$ for $\delta^{13} \mathrm{C}(1 \sigma)$ and $0.08 \%$ for $\delta^{18} \mathrm{O}(1 \sigma)$.

\section{PETROGRAPHY}

\section{Host-Rock and Dolomite Types D1 and D2}

The Jurassic Sahtan Group in Wadi Mistal comprises bluish gray to brown host-rocks. The bluish gray lithologies are limestone, some containing centimeter-size calcite nodules. The brown lithologies are partially dolomitized limestone or dolostone that are parallel to the 


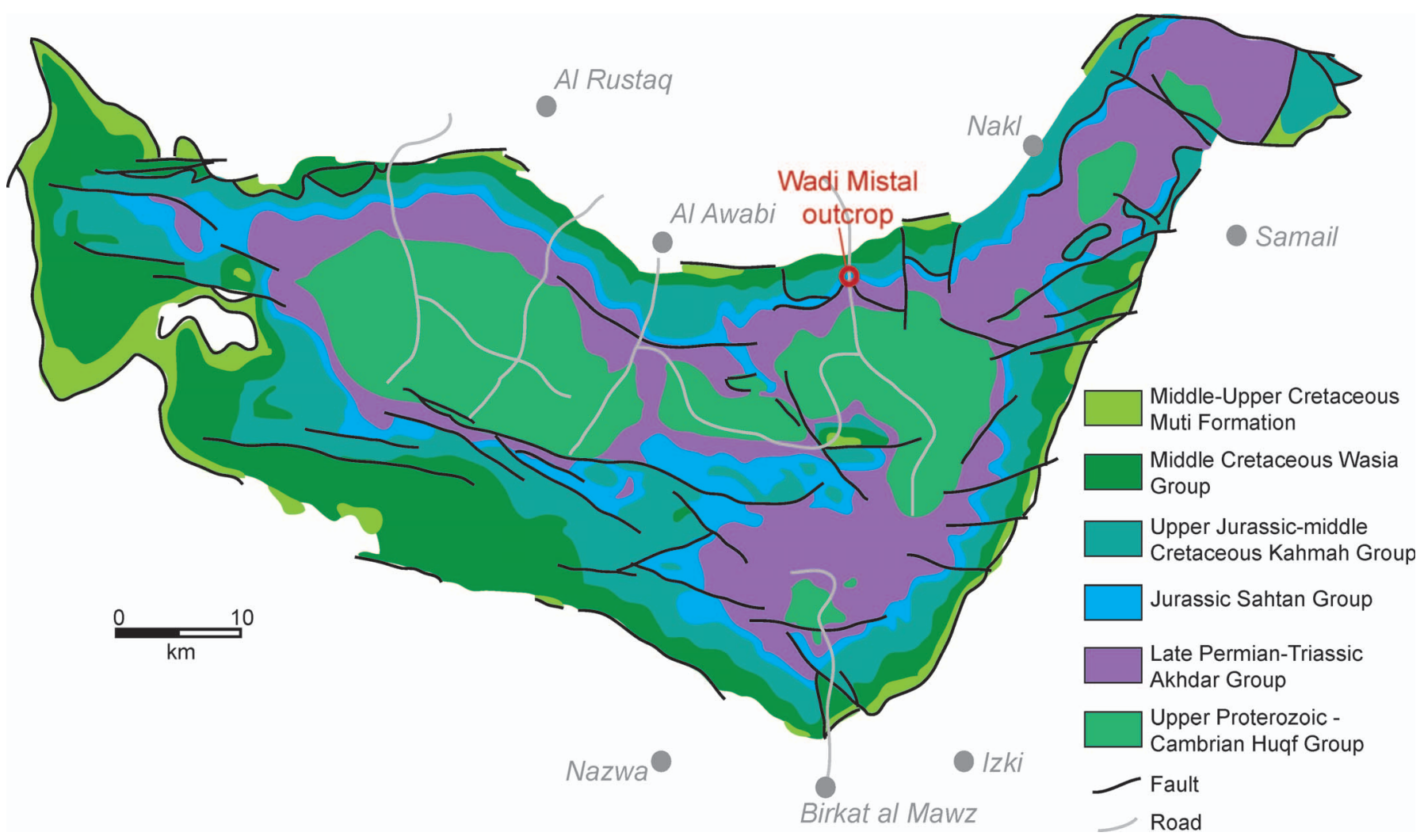

FIG. 2.-Geological map of the Jebel Akhdar tectonic window (after Le Métour et al. 1993). Location of the Wadi Mistal outcrop is indicated.

bedding and are termed here stratabound dolostone (SBD). A third lithology, a brick-red dolostone with iron oxides, follows a fault, hence is referred to as fault-related dolostone (FRD). This dolostone zone extends a few meters away from the fault along stratigraphic layers (Fig. 3). A few reddish veins crosscut limestone and SBD; these veins are filled with brick-red dolomite as in FRD. This crosscutting relationship illustrates that the FRD is younger than the SBD.
Petrographic study of thin-sections of the host-rocks identified several carbonate textures. The textures of bluish gray limestone vary between mudstone to wackestone and packstone with peloids or calcite-cemented fenestrae, and the rocks contain nodules or fossil relicts (such as echinoids) generally 100 to $1000 \mu \mathrm{m}$ in length (Fig. 4A), although larger shell or coral fragments occur. The larger nodules (several centimeters in diameter) in the limestone are filled mainly with coarse gray and white

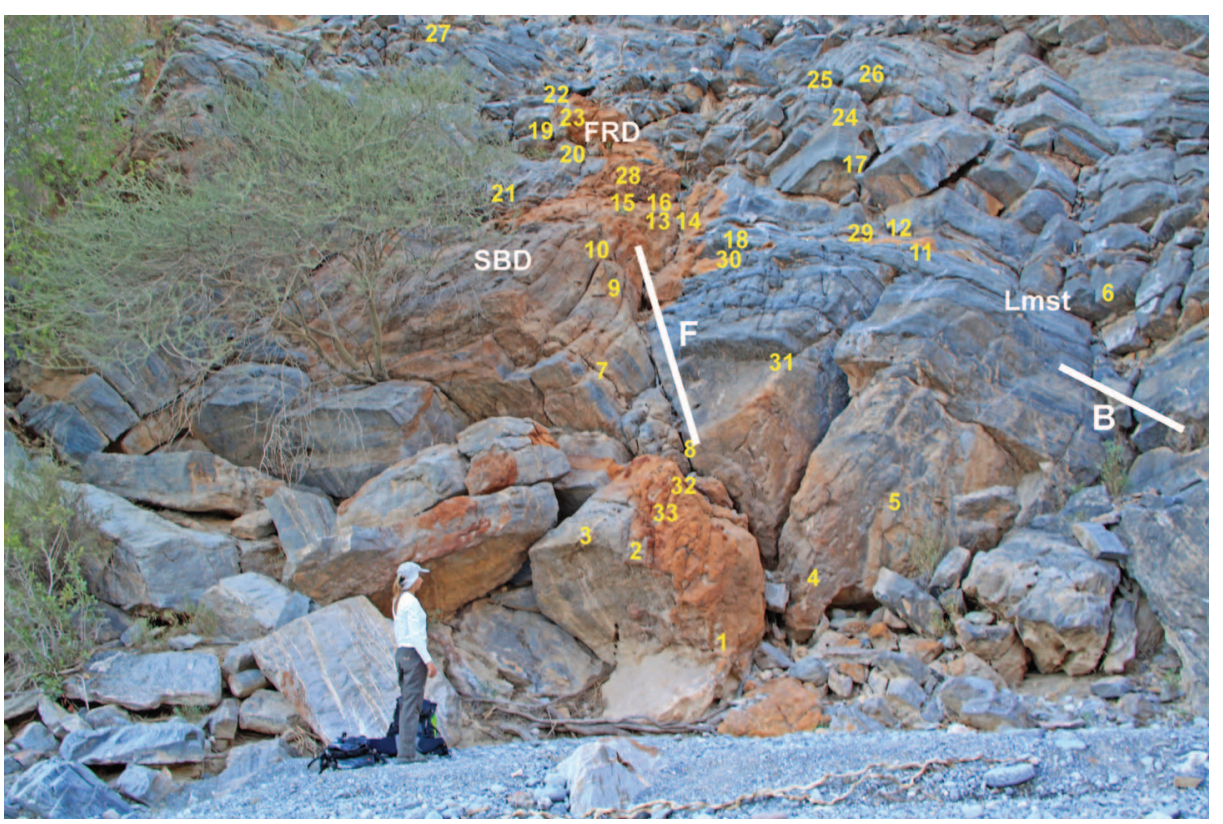

FIG. 3.-Photograph of the sampled outcrop of Jurassic rocks. The picture shows the bluish gray limestone (Lmst), the brown stratabound dolomite layers (SBD), and the red fault-related dolomite body (FRD). The numbers indicated on the picture refer to the sample numbers and show their locations. The two white lines indicate the bedding $(\mathrm{B})$ and fault $(\mathrm{F})$ orientation. 

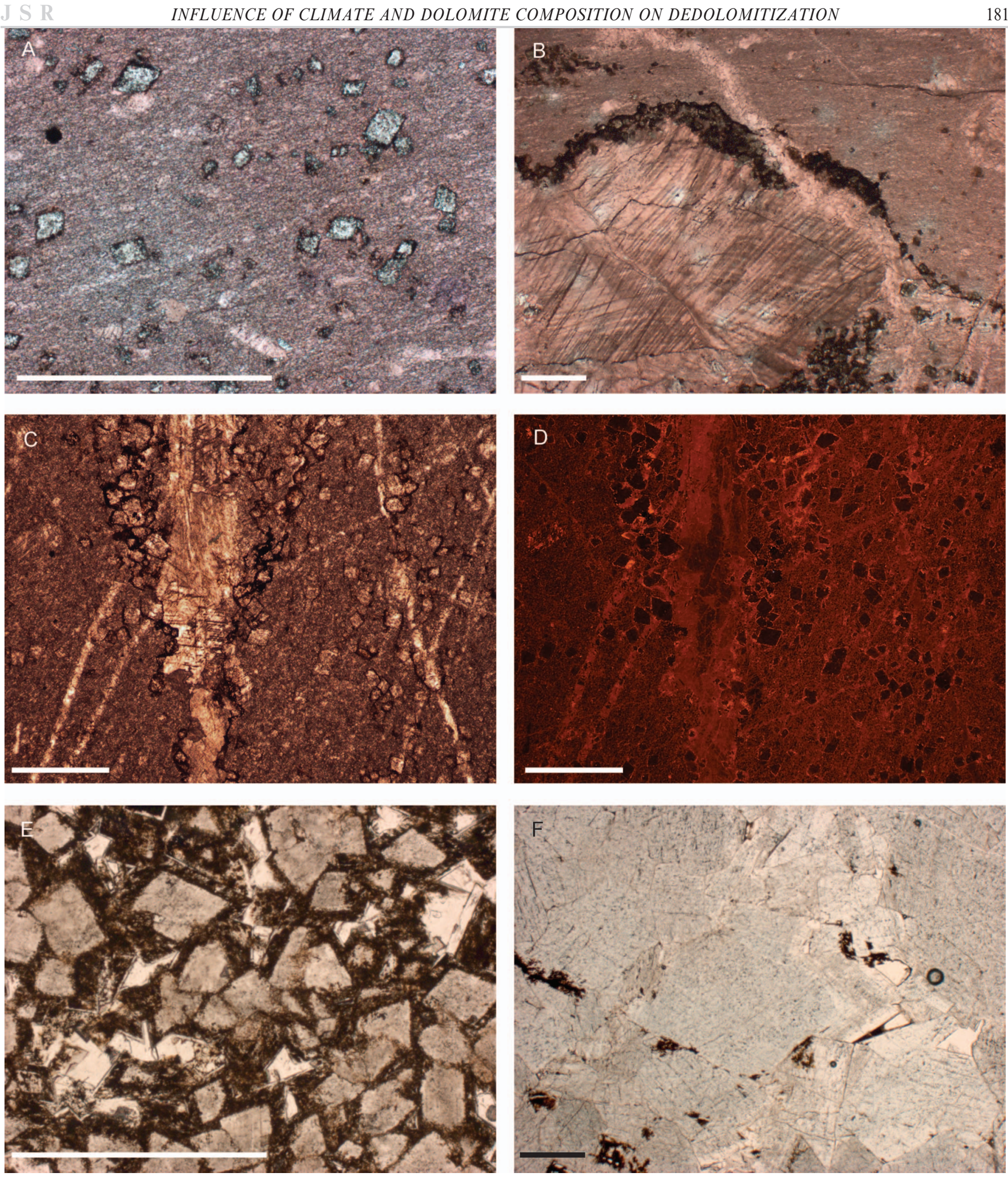

FIG. 4.-Microphotographs of thin-sections of the different rock types. Scale bars are $500 \mu \mathrm{m}$. A) Stained thin-section of host-rock limestone containing some small dolomite rhombs. B) Stained thin-section of nodule-bearing limestone, showing recrystallized limestone matrix and highly deformed calcite crystals in nodule with crosscutting and bent cleavage twin planes. Small brown D1 dolomite crystals are concentrated at the rim of the nodule and in clusters inside the nodule and in the host-rock. An irregular calcite vein crosscuts the dolomite and calcite in the nodule. C) Unstained thin-section of limestone, showing some D1 dolomite rhombs, of which a few seem corroded by the stylolite. Note that the top of the layer is oriented to the left. D) Same view as part C but under cathodoluminescence. Note that the midtones were lightened by a factor of 2 to make luminescent features visible in this photograph. The dolomite rhombs are nonluminescent to the naked eye, whereas the limestone host-rock is dull dark red. E) Unstained thinsection from brown stratabound dolostone with planar-s to planar-e D1 dolomite. The dolomite rhombs have a dark brown outer core, and some rhombs have also a thin clear rim. The former pore space between the dolomite rhombs is filled with clear calcite. F) Stained thin-section of coarse fault-related D2 dolomite. The blue shade due to the staining suggests this dolomite has a high iron concentration. Some dark brown zones due to alteration are present, mainly at the rims of the crystals. 

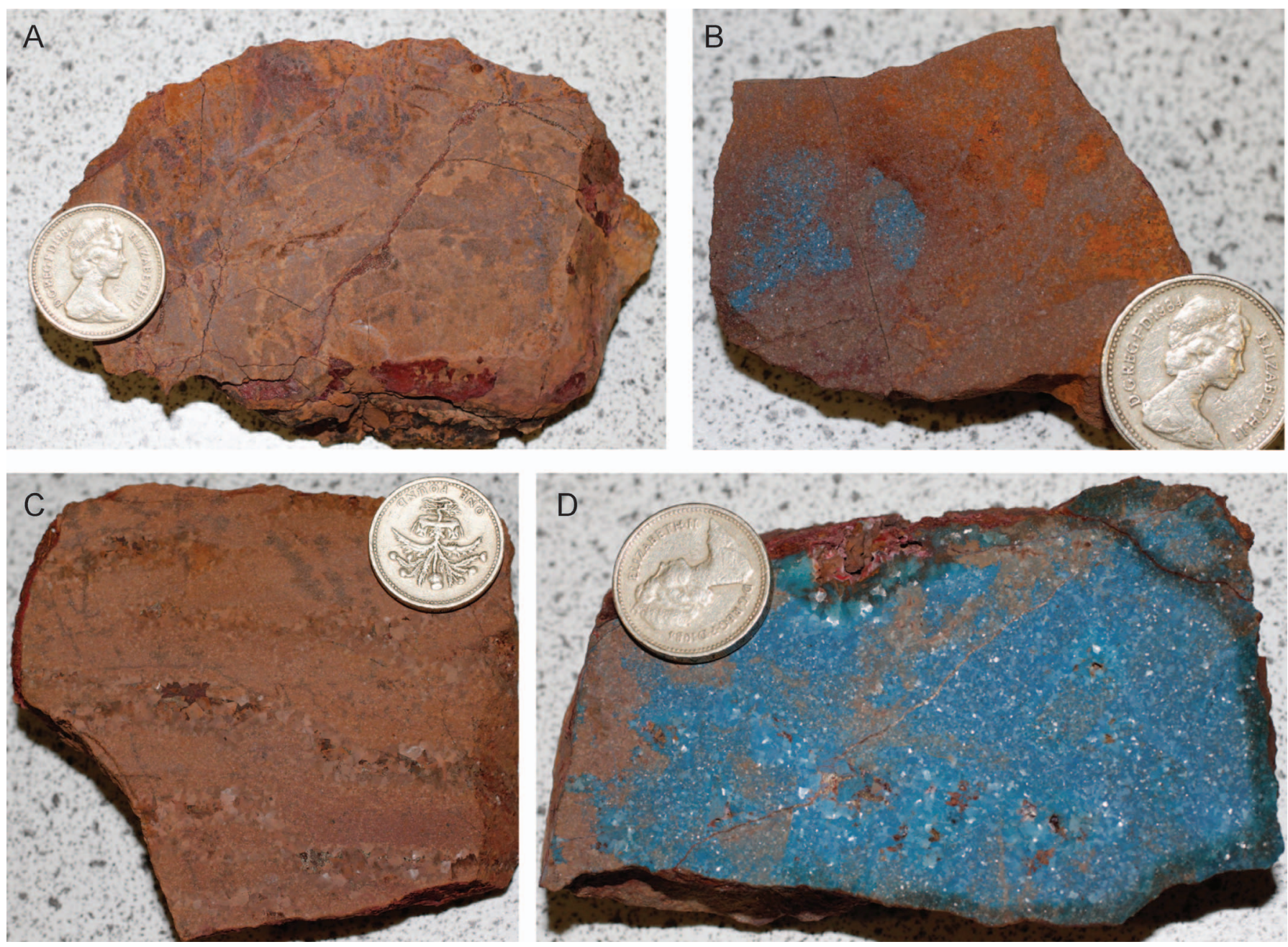

FIG. 5.-Macrophotographs of polished and stained samples. Coin has a diameter of $2.3 \mathrm{~cm}$. A) Calcitized sample. B) Partially altered dolomite sample with alteration front; blue-stained Fe-rich zone with pristine dolomite and red-brown zone with dolomite, goethite, and some calcitized parts. C) Slightly calcitized altered red brown dolomite sample. D) Blue-stained Fe-rich pristine dolomite with some altered noncalcitized red-brown dolomite at the sample rim.

calcite and occasionally minor brown dolomite and white quartz cement. The cement in the nodules is deformed strongly, with crosscutting and bent cleavage twins in the calcite crystals (Fig. 4B). These calcite crystals are nonluminescent or show a dull dark reddish orange luminescence under CL. Quartz crystals are nonluminescent, and dolomite is mainly nonluminescent under CL but can show dull reddish zones. The limestone can contain small (30 to $150 \mu \mathrm{m}$ ) subhedral to euhedral dolomite crystals (hereafter referred to as "D1") and, more rarely, a few diagenetic quartz crystals. The D1 dolomite rhombs occur scattered in the limestone but are more abundant along stylolites and stylolitic seams. The D1 rhombs commonly have a dark brown rim (Fig. 4C). The D1 dolomite crystals are commonly nonluminescent under CL (Fig. 4D), but in a few cases they can display a reddish weakly luminescent rhomb-shape lining in the core of the crystal. In general, the limestone is strongly recrystallized, which transformed the original muddy matrix to a coarser crystalline texture and recrystallization also partly obliterated fossil relict structures (Fig. 4A). The calcitic matrix is nonluminescent to dull dark red with some brighter greenish orange luminescent crystal rims under CL.

The brown SBD lithologies are partially to completely dolomitized, and the dolomite can be classified as planar-s to planar-e dolomite with crystals of 50 to $200 \mu \mathrm{m}$ in diameter; in some cases, a few small zones contain coarser subhedral crystals of up to $500 \mu \mathrm{m}$ in diameter. Some D1 crystals in SBD have a dark brown outer core or a thin clear dolomite rim (Fig. 4E) and are nonluminescent or dark red under CL. Intercrystalline pore space between D1 crystals can be filled with dark brown material or with clear calcite. The dark brown material between the crystals can display some dull reddish luminescence under CL, especially near the dolomite crystal borders. In a few samples, the D1 rhombs are cut by bedding-parallel stylolites. This light brown dolomite is similar to the small dolomite rhombs in the limestone, hence it is also classified as "D1."

In thin-section, the brick-red FRD includes coarser (200 to $1500 \mu \mathrm{m}$ diameter) ferroan dolomite (determined based on blue color upon staining; Fig. 4F), hereafter referred to as "D2." The D2 dolomite crystals can be rhombic, but most are anhedral and can be saddle dolomite where the crystals occur adjacent to pore spaces or calcite cement. It includes many reddish brown to dark brown zones, besides small D1 dolomite rhombs similar to those present in the host-rocks. Polished and stained hand samples from FRD (Fig. 5) illustrate macroscale textures. The white parts (under transmitted polarized light) of the ferroan D2 dolomite are nonluminescent under CL and the dark brown and reddish brown zones (under transmitted polarized light) are either nonluminescent or display dull or bright dark red and reddish orange luminescence. The reddish brown and dark brown zones also 

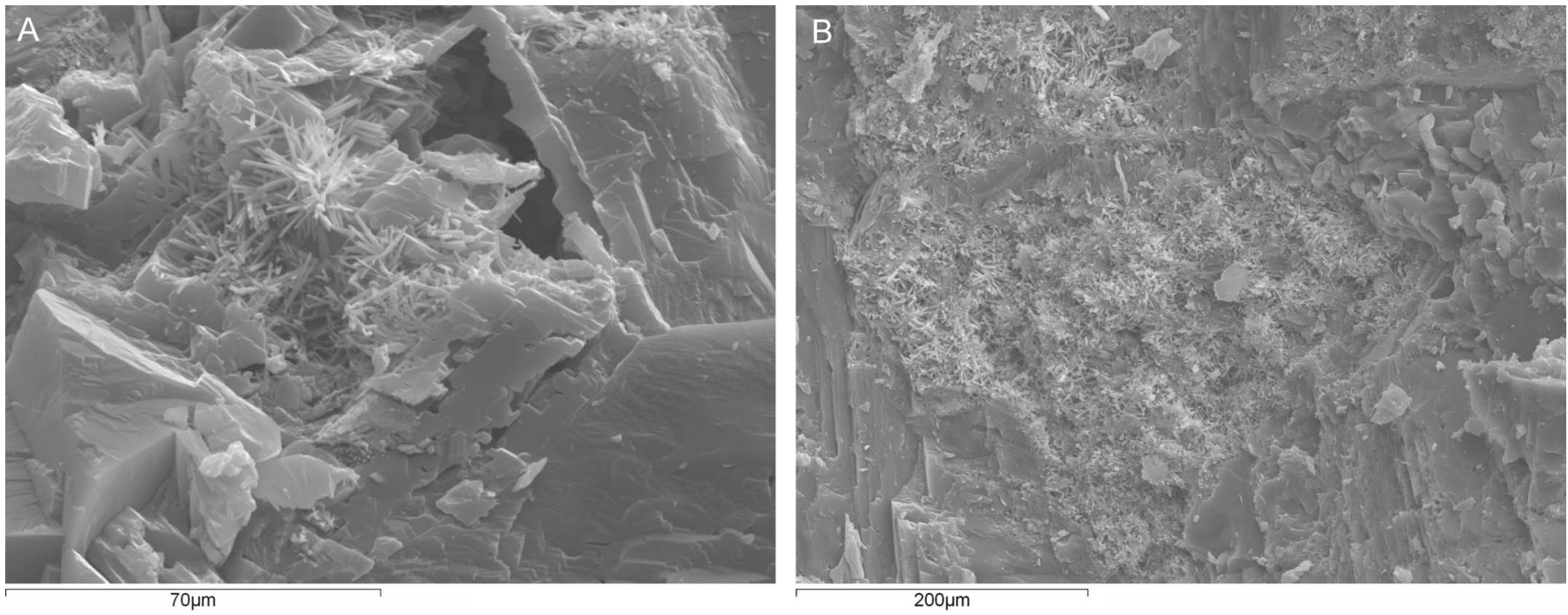

FIG. 6.-SEM photographs of two examples of altered fault-related dolomite (FRD) with dissolution textures of dolomite and precipitated goethite needles and calcite.

include goethite, which forms radiating clusters of prismatic crystals (Fig. 6). XRD analyses indicate up to 5\% goethite in the samples from the red dolomite body. However, thin-section analysis supports a small amount of goethite within more extensive reddish brown zones. Intercrystalline porosity between the coarse D2 crystals commonly is filled by calcite that can be nonluminescent under CL, dull brown luminescent, bright orange luminescent, or that can display a zoned luminescence pattern with alternating nonluminescent, dull brown and bright yellowish orange luminescent zones.

\section{Alteration Textures}

Replacement of dolomite by calcite is indicated by rhombs in stained thin-sections that were originally dolomitic that take a pink stain, indicating calcite, and by XRD analyses (based on the typical dolomite rhomb crystal shape and XRD-confirmed abundance of dolomite in less altered or unaltered samples and higher abundance of calcite in more altered samples from the same outcrop). These dedolomites include several alteration textures. As discussed below, alteration can occur in different degrees, whereby dolomite may be oxidized (with the formation of goethite) or affected by calcitization (i.e., dedolomitization).

In the limestone, D1 crystals can be calcitized either partially or completely, resulting in two main textures (Fig. 7). There is no difference in spatial concentration of one texture versus the other. The two textures occur in similar abundance, and both textures can be present in a single sample or thin-section. The first texture consists of rhombs that are characterized by calcitized patches commonly at the corners or the rims of the rhombs (Fig. 8A). Calcitized zones in D1 rhombs are nonluminescent under CL; they commonly are not distinguishable from the nonluminescent dolomite unless they crosscut the dull reddish luminescent small rhomb lining in the core of the crystal. The second texture consists of rhombs that are calcitized completely. The rhombs are composed of either fine crystalline calcite, appearing similar to the recrystallized limestone, or medium crystalline calcite. The edges of the rhombs can be accentuated by a dark brown rim or by a black coating, especially where the rhombs occur close to stylolites (Fig. 8B). The rhombs are nonluminescent under $\mathrm{CL}$, whereas the dark brown rims can display a dull reddish luminescence.

Relative to the limestone, the brown SBD lithologies are slightly less altered. Most samples show dedolomitization textures similar to those in the small dolomite rhombs in the limestone, as discussed above. The calcitized rhombs or partial rhombs can include nonluminescent cleavagetwinned calcite crystals (Fig. 8C, D). Some samples, however, are not affected by calcitization, but display a dark brown zone at the core-rim interface or a dedolomitization-altered rim. This dark brown zone can display a very weak dull dark red luminescence under CL.

The most altered part of the outcrop is the brick-red FRD body (Figs. 3, 5). It is clear that alteration zones in this brick-red FRD body are concentrated at the rock surface and along fractures. A series of textures are evident in the FRD, each of which includes different degrees of alteration (Fig. 9). A texture close to the original D2 dolomite is marked by coarse iron-rich D2 dolomite crystals that are barely affected by alteration (Fig. 8E). These D2 crystals are mainly white in color, but can display a few brown patches at crystal borders or growth zones or cleavage planes (Fig. 9B). The unaffected part of D2 is nonluminescent under CL, whereas the dark brown patches are bright reddish orange luminescent (Fig. 8F). Commonly, D2 is affected by alteration, which has led to several textures of brownish altered zones. These zones can have the following textures:

(1) Calcitized nonluminescent zonation in brown coarse crystals (Figs. 9C, 10A).

(2) Small, thin colloform brown bands in calcitized zones (Figs. 9D, 10B). No cathodoluminescence zonations are evident under CL, but these include a homogeneous dull to bright red luminescence.

(3) Dark brown or reddish brown homogeneous millimeter-scale area containing several crystals (Fig. 9E) or subhedral crystals in veins (Fig. 10C). Crystals in these areas or veins are mainly nonluminescent under CL, but some contain dull dark brown luminescent patches. In rare cases, however, the dark brown zones can display a dull to bright red luminescence under CL (Fig. 10D).

(4) Reddish brown fishbone-like calcitized texture with preserved small D1 rhombs (Figs. 9F, 10E). Dark brown zones are nonluminescent to dull dark brown luminescent under CL, whereas reddish brown and clear calcite patches display a bright orange luminescence (Fig. 10F). Preserved small D1 rhombs are nonluminescent to dull dark brown luminescent under CL, but some display a dull luminescent rhomb lining in the core.

(5) Reddish brown fishbone-like calcitized texture with calcitized small D1 rhomb relicts (Fig. 9G, 10G). This dedolomitization pattern has the same characteristics as the previous texture except that the small rhombs are calcitized, not preserved, D1; the rhombs are nonluminescent under CL. 


\section{Pristine rock fabric}

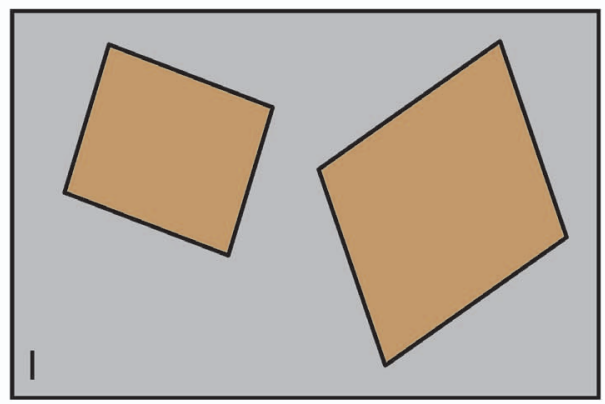

Partially altered textures
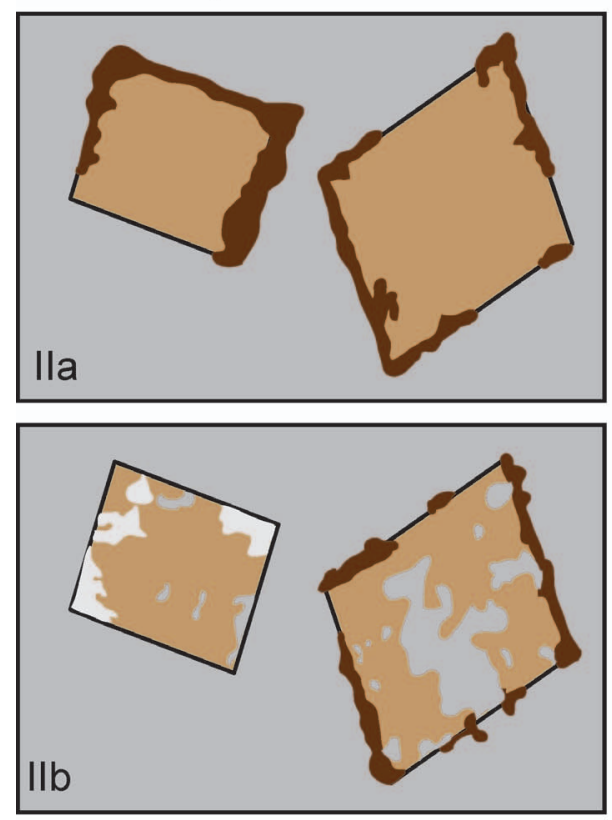

Fine-crystalline calcite Dolomite

\section{Completely calcitized textures}
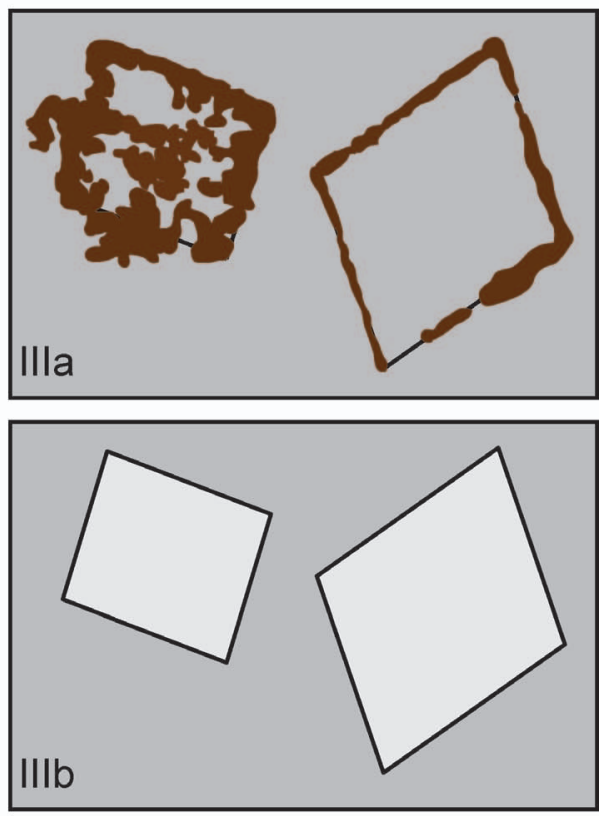

Medium-crystalline calcite

Dark brown staining
FIG. 7.-Alteration textures of dolomite rhombs in the bluish gray limestone. The original rock texture is presented in fabric I. Rock textures resulting from some degree of alteration are shown in fabric IIa, with a dark brown coating developed along the rims of the dolomite rhombs, and fabric IIb, whereby part of the dolomite is calcitized. Completely calcitized textures can occur as fabric IIIa, whereby the rhomb is filled with fine-crystalline calcite that has the same appearance as the surrounding recrystallized limestone, or fabric IIIb, where the rhomb is filled by calcite that is coarser than the surrounding recrystallized limestone.
(6) Mottled dark brown pattern in partially calcitized reddish brown zone (Fig. 9H, 10H). Dark mottles are nonluminescent in a dull reddish luminescent zone under CL.

\section{CARBONATE GEOCHEMISTRY}

\section{Major-Element and Minor-Element Geochemistry}

The concentrations of $\mathrm{Fe}, \mathrm{Mn}, \mathrm{Ca}$, and $\mathrm{Mg}$ vary in the samples from the bluish gray limestone, the brown SBD and the red FRD (Table 1). Elemental data from SBD bulk carbonate represent a signature of D1 dolomite influenced by the presence of both non-dolomitized limestone and calcitized D1, whereas the signature of the FRD bulk carbonate shows the signature of mainly D2 (and traces of D1) affected mainly by the presence of calcitized D2 (Table 1). Since the FRD dolomite fraction is composed mainly of D2 and because potential D1 traces do not have a marked influence on the total chemical composition of the FRD dolomite fraction, the FRD dolomite fraction will be referred to as D2 in the text below.
The $\mathrm{Mg}$ concentration varies over a wide range in the bulk carbonate samples, but it is restricted to a narrower range in the limestone and D1 and D2 (Fig. 11A). The Mg concentration is very low $(0.1-0.7 \mathrm{wt} \%)$ in the limestone, whereas higher concentrations are found in D2 (8.5-11.1 wt \%) and the highest $\mathrm{Mg}$ concentrations are measured in D1 (11.4-13.8 wt \%). The highest $\mathrm{Fe}\left(5-9 \mathrm{wt}^{0} \%\right)$ and $\mathrm{Mn}(0.3-0.4 \mathrm{wt} \%)$ concentrations are evident in FRD samples that are least affected by alteration. The other FRD samples have Fe and Mn concentrations that show some overlap with the generally lower Fe and especially lower Mn concentrations of the limestone, D1, and SBD bulk carbonate samples (Fig. 11A, B).

\section{Dolomite Stoichiometry}

Most D1 samples have a nearly stoichiometric composition (50-51 mol\% $\mathrm{CaCO}_{3}$, Table 1). Similarly, the well-preserved white coarse ferroan D2 have about $50 \mathrm{~mol} \% \mathrm{CaCO}_{3}$. However, the majority of D2 samples are affected by alteration (with goethite formation) and the altered reddish D2 samples are composed of $56-57 \mathrm{~mol}^{2} \% \mathrm{CaCO}_{3}$ (Fig. 12). 

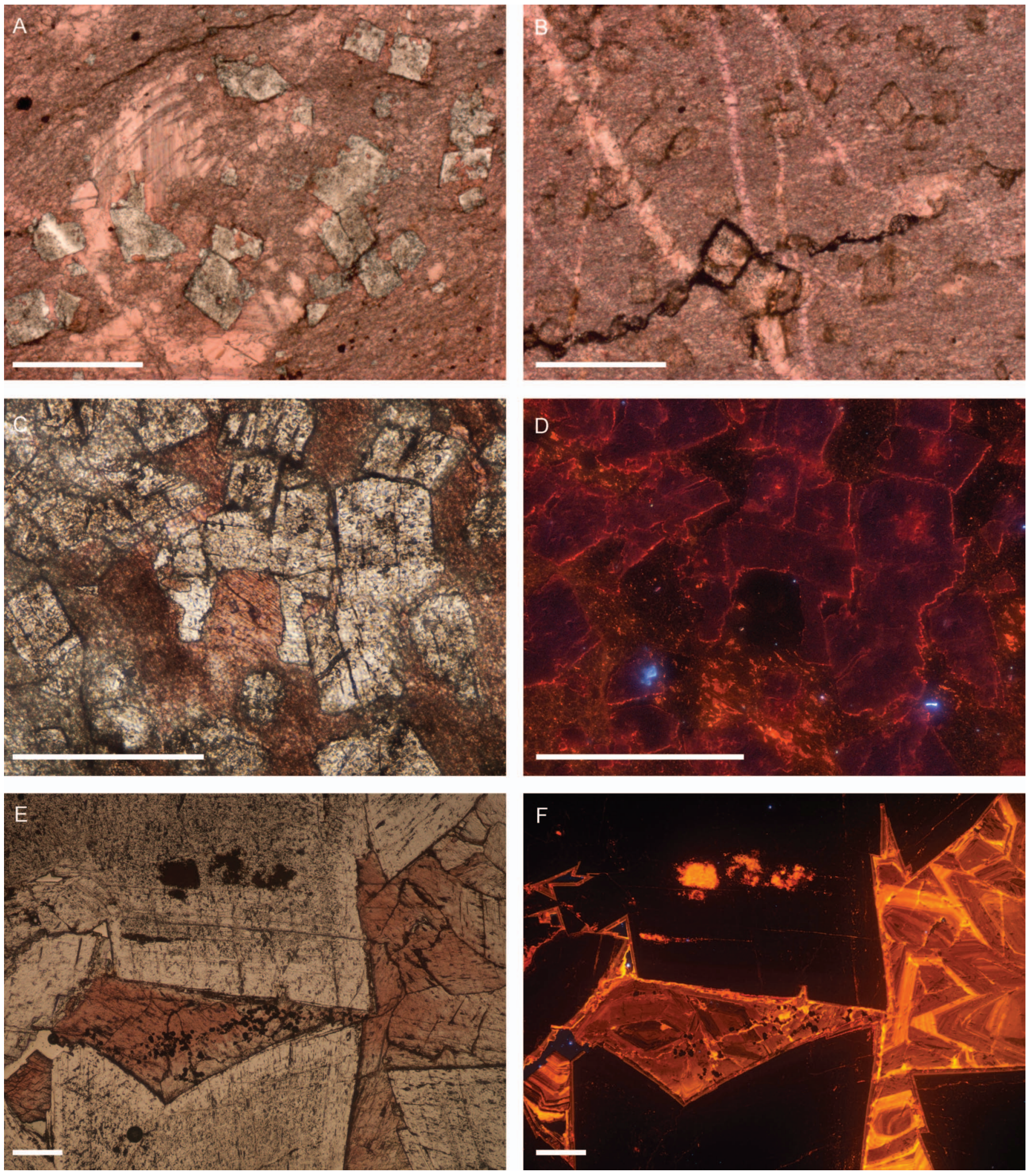

FIG. 8. - Microphotographs of alteration textures in stained thin-sections. Scale bars are $250 \mu \mathrm{m}$. A) D1 dolomite rhombs that are partially replaced by calcite in a recrystallized limestone. B) Recrystallized limestone with D1 rhomb relicts after alteration. C) D1 dolomite in stratabound dolomite zone with some recrystallized limestone zones. Partially calcitized dolomite rhomb in center with cleavage twins in the replacing calcite. D) Same view as part $\mathrm{C}$ but under cathodoluminescence. With the naked eye, all is nonluminescent and the digital image has been reworked and brightened. The cleavage-twinned dedolomite is darker (less luminescent) than the dolomite rhombs. E) Subhedral coarse D2 dolomite with minor dark brown patches and calcite fill in former pore space between the dolomite crystals. F) Same view as part E but under cathodoluminescence. The coarse dolomite is nonluminescent, whereas the dark brown patches are bright orange luminescent. The pore-filling calcite displays a zoned pattern of dull and bright orange luminescent zones. 


\section{Pristine dolomite fabric}

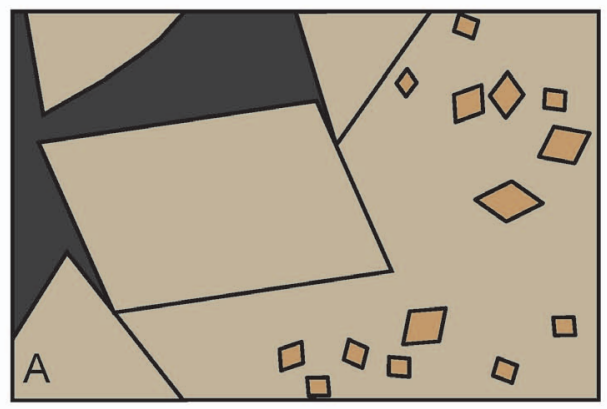

Alteration textures
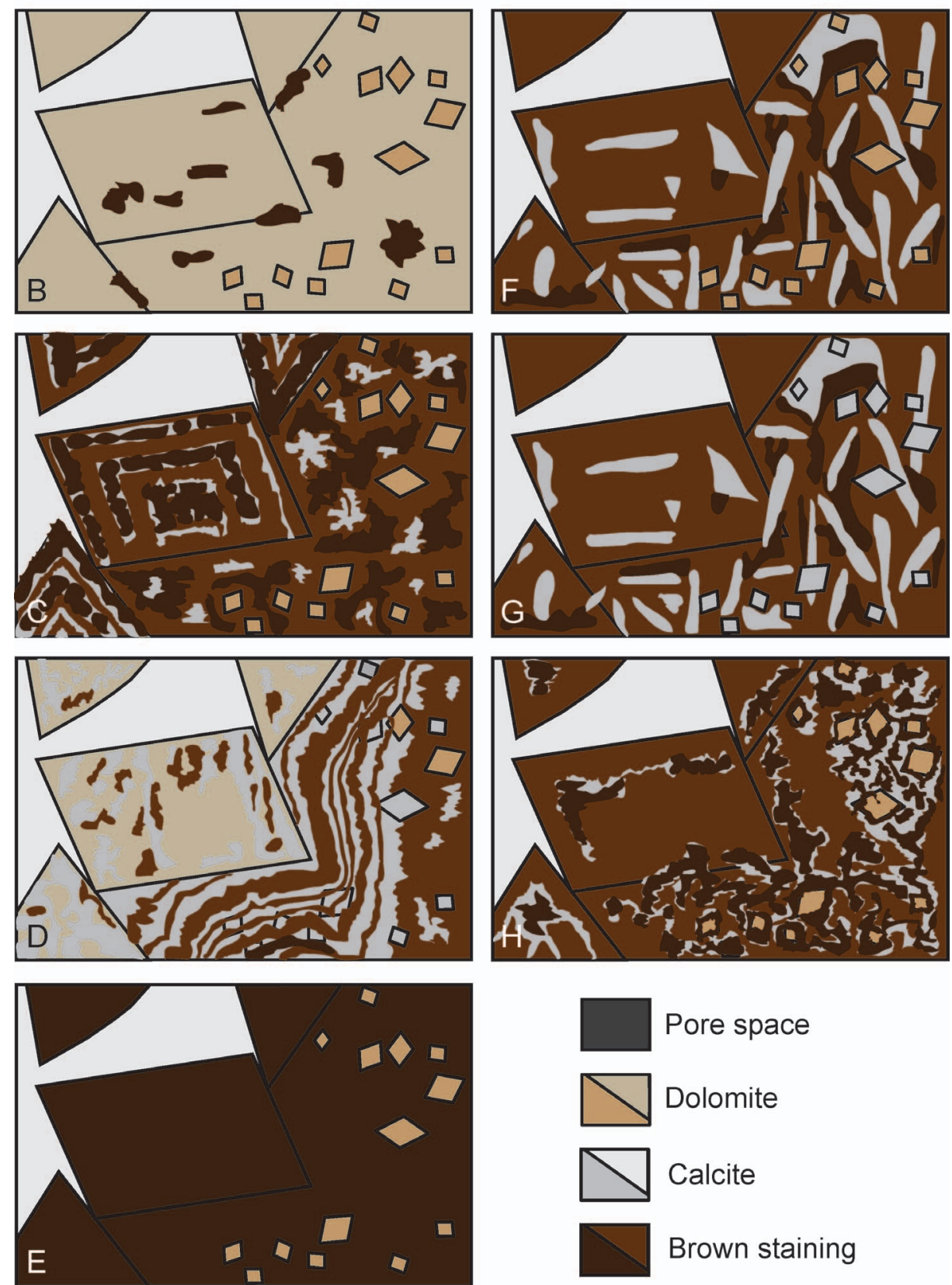

Pore space

Dolomite

Calcite

Brown staining
FIG. 9.-Alteration textures of fault-related dolomite fabric. A) Pristine dolomite fabric with orange brown dolomite rhombs representing D1 and gray-brown coarser dolomite representing D2. B) Well-preserved texture with coarse ironrich D2 dolomite crystals that can display a few brown patches at crystal borders or growth zones or cleavages. C) Brown and calcitized zonations and darker and lighter brown irregular mottles in the coarse D2 crystals. D) Small thin colloform brown bands and calcitized zones. Part of the D2 dolomite may be better preserved also D1 crystals may or may not be calcitized. E) Dark brown or reddish brown homogeneous large zone in D2 dolomite, whereas D1 dolomite rhombs may be preserved. F) Reddish brown fishbone-like calcitized texture with preserved small D1 rhombs. G) Reddish brown fishbonelike calcitized texture with calcitized small D1 rhomb relicts. $\mathbf{H}$ ) Mottled dark brown pattern in partially calcitized reddish brown zone and some preserved D1 dolomite rhombs. 


\section{Stable Carbon and Oxygen Isotope Ratios}

A cross-plot of the stable carbon and oxygen isotope ratios of the various sampled phases (Fig. 13) reveals that bulk limestone samples have a wide range of $\delta^{18} \mathrm{O}$ values (between -9.3 and $-4.5 \%$ ) and $\delta^{13} \mathrm{C}$ values (between -1.8 and $+2.4 \%$ VPDB). These $\delta^{13} \mathrm{C}$ values are similar to Jurassic marine signature (Veizer et al. 1999), and $\delta^{18} \mathrm{O}$ values are more negative. The pristine D2 samples have $\delta^{18} \mathrm{O}$ values between -9.8 and $-7.6 \%$ and $\delta^{13} \mathrm{C}$ values between +1.5 and $+2.1 \%$ VPDB. The D1 samples have a less negative $\delta^{18} \mathrm{O}$ signature $(-5.0$ to $-1.8 \%$ VPDB $)$ and a $\delta^{13} \mathrm{C}$ signature $(+2.0$ to $+2.7 \%$ VPDB) close to that of D2. The altered, red, noncalcitized D2 samples have less negative $\delta^{18} \mathrm{O}$ values, compared to the pristine D2, and the altered, rusty, noncalcitized D2 samples have the least negative $\delta^{18} \mathrm{O}$ signature of this study. The degree of alteration of the dolomite samples coincides thus with a shift towards more positive $\delta^{18} \mathrm{O}$ values. In D2 samples in which dolomite was replaced by calcite ("calcitized D2"), a decreasing trend in the $\delta^{13} \mathrm{C}$ value (from an average of +1.0 to $-4.8 \%$ VPDB) is evident, whereas the $\delta^{18} \mathrm{O}$ is slightly lower than the altered noncalcitized D2. The values of the altered red dolomite veins fall close to a mixing line correlating altered, red, noncalcitized D2 and calcitized D2.

\section{DISCUSSION}

\section{Composite Textures Originating from both Dolomitization and Alteration}

A wide variety of textures was documented that must reflect (part of) the diagenetic history of the rocks. In outcrop, most stratigraphic layers contain some small dolomite rhombs (D1 dolomite), whereas the D2 dolomite seems to be associated only with fault zones. Presenting a model of how the dolomite formed is not the focus of this study, and thus the discussion is limited to dolomite characteristics, as far as it is relevant to understanding the alteration processes. One important fact is that there are two dolomite types, i.e., stratabound D1 and fault-related D2, each marked by different characteristics. The petrographic difference is crystal size, i.e., fine D1 versus coarse D2, and also texture, i.e., subhedral to euhedral D1 rhombs and a variety of euhedral but mainly anhedral and saddle dolomite D2. Similarly, the geochemical characteristics are different. D1 is non-ferroan, whereas D2 is ferroan, and the stable oxygen isotope composition in pristine D2 is about 5\% more negative than that in D1. Based on the fact that stratabound D1 dolomite layers are crosscut by veins with D2 dolomite, and that small D1 dolomite rhombs are surrounded or enclosed by D2 dolomite, D2 must have formed after D1.

The alteration textures and presence of calcitized dolomite indicate that at least one major phase of alteration and dedolomitization took place. In addition, some petrographic observations can be interpreted as evidence for another, earlier phase of dedolomitization preceding the main event. Calcitized D1 rhombs can be composed of fine-crystalline calcite, similar to the composite calcite rhombohedra texture (Shearman et al. 1961; Evamy 1967). However, it is possible that this fine-crystalline texture is not the original dedolomite texture in the studied rocks, since the finecrystalline calcitized D1 rhombs have the same texture as the surrounding recrystallized limestone. The similarity with the recrystallized limestone texture and, in addition, the occurrence of cleavage twins in coarser crystalline calcitized D1 rhombs point to burial recrystallization of dedolomitized D1 in the SBD. Calcitization under burial conditions is possible, and limited dissolution of dolomite during burial was recorded in Cretaceous rocks of the Zagros Mountains of Iran (Sharp et al. 2010). For dedolomitization to occur, an increase in the $\mathrm{Ca} / \mathrm{Mg}$ ratio or a decrease in the salinity of the pore fluids (Khalaf and Abdal 1993) would be expected.

Evidence for burial dedolomitization is present only in D1, whereas the alteration of D2 testifies to a second and major alteration and dedolomitization phase that is interpreted as a late post-uplift surface weathering process based on the depleted stable isotope signature (both $\delta^{18} \mathrm{O}$ and $\delta^{13} \mathrm{C}$ ) of calcitized D2 typical of rain-water oxygen and soilrelated carbon (e.g., Sanz-Rubio et al. 2001; Cantrell et al. 2007; Nader et al. 2008; see more extensive discussion in the next section). This phase of weathering and dedolomitization affected D2 extensively but spared some D1 in all lithologies (i.e., limestone, SBD as well as FRD). The fact that D2 was more altered, and thus less stable during the second dedolomitization event than D1, would be consistent with a near-surface origin for the second alteration phase, as previous authors have reported that Fe- and Mn-rich dolomite similar to D2 is less stable in the nearsurface environment (e.g., Al-Hashimi and Hemingway 1973), whereas nonferroan dolomite (such as D1) is more stable at surface conditions. It is clear based on mineralogy that D2 was affected by oxidation of the unstable dolomite, generating iron oxides and hydroxides, recrystallization of dolomite, and calcitization of dolomite. The association of iron oxides with dedolomitized carbonate rocks is common (Shearman et al. 1961; Folkman 1969; Katz 1971; Frank 1981). Evamy (1963) interpreted that the excess of ferrous iron was expelled during dedolomitization and precipitated as colloidal ferric hydroxide under specific physicochemical conditions. However, oxidation of ferroan dolomite is not necessarily accompanied by calcitization of dolomite. Subaerial exposure can convert ferroan dolomite into iron oxide grains or aggregates by oxidation and pseudomorphic replacement (Zeidan and Basyuni 1998; Grosz et al. 2006). The fact that goethite is formed rather than hematite (no relicts or pseudomorphs of hematite are present) is also consistent with conditions of low temperature and $\mathrm{pH}$ found at surface conditions, high water activity $\left[\mathrm{H}_{2} \mathrm{O}\right]$, and low iron supply rates (Yapp 2001). The interpreted surface weathering textures can be grouped into two end products: (1) goethite-dolomite fabric, resulting from oxidation of dolomite with the formation of iron oxides and texture-preserving recrystallization of dolomite, and (2) goethite-calcite fabric, resulting from a combination of oxidation of dolomite and calcitization (or pseudomorphic replacement of dolomite by calcite, i.e., dedolomitization). The two fabrics occur intimately mixed in the outcrop.

\section{New Insights on the Dedolomitization Process and the Influence of Climate}

Stable isotope ratios of oxygen in carbonate phases depend on the precipitation temperature and the composition of the fluid from which the carbonate precipitates. Stable carbon isotope compositions in nearsurface carbonate cements, such as speleothems, reflect input from (i) soil $\mathrm{CO}_{2}$, which is controlled by atmospheric $\mathrm{CO}_{2}$, plant respiration, and organic-matter degradation and (ii) bedrock carbonate that is dissolved during seepage (Genty et al. 2006). In some dedolomitization studies, isotopic compositions were presented as a strong argument to prove that dedolomitization happened near the surface by meteoric fluids (low $\delta^{18} \mathrm{O}$ of -11 or $-6 \%$ VPDB and low $\delta^{13} \mathrm{C}$ of about -6 to $-8 \%$ VPDB as in Cantrell et al. 2007; Nader et al. 2008). Stable isotope results here show two clusters of data, one for the goethite-calcite fabric and one for the goethite-dolomite fabric. Similarly to previous studies that suggested that dedolomitization is driven by surface meteoric fluids (e.g. Sanz-Rubio et al. 2001; Cantrell et al. 2007; Nader et al. 2008), calcite resulting from pseudomorphic replacement of D2 (indicated as "calcitized D2" in Fig. 13) has a signature of both depleted $\delta^{18} \mathrm{O}$ and depleted $\delta^{13} \mathrm{C}$, typical of rain-water oxygen and soil-related carbon. As mentioned in the previous section, the depleted isotopic signature of the calcitized D2 is one of the main arguments to interpret the second dedolomitization phase as being associated with surface weathering. In this context, low carbon isotope values for the calcitized dolomite would be indicative of a high percentage of carbon input from soil $\mathrm{CO}_{2}$ in comparison with carbon input from the surrounding rock. An alternative model to explain the depleted isotopic values of the calcitized D2 would be to associate dedolomitization with deep burial (low $\delta^{18} \mathrm{O}$ due to higher temperature of 

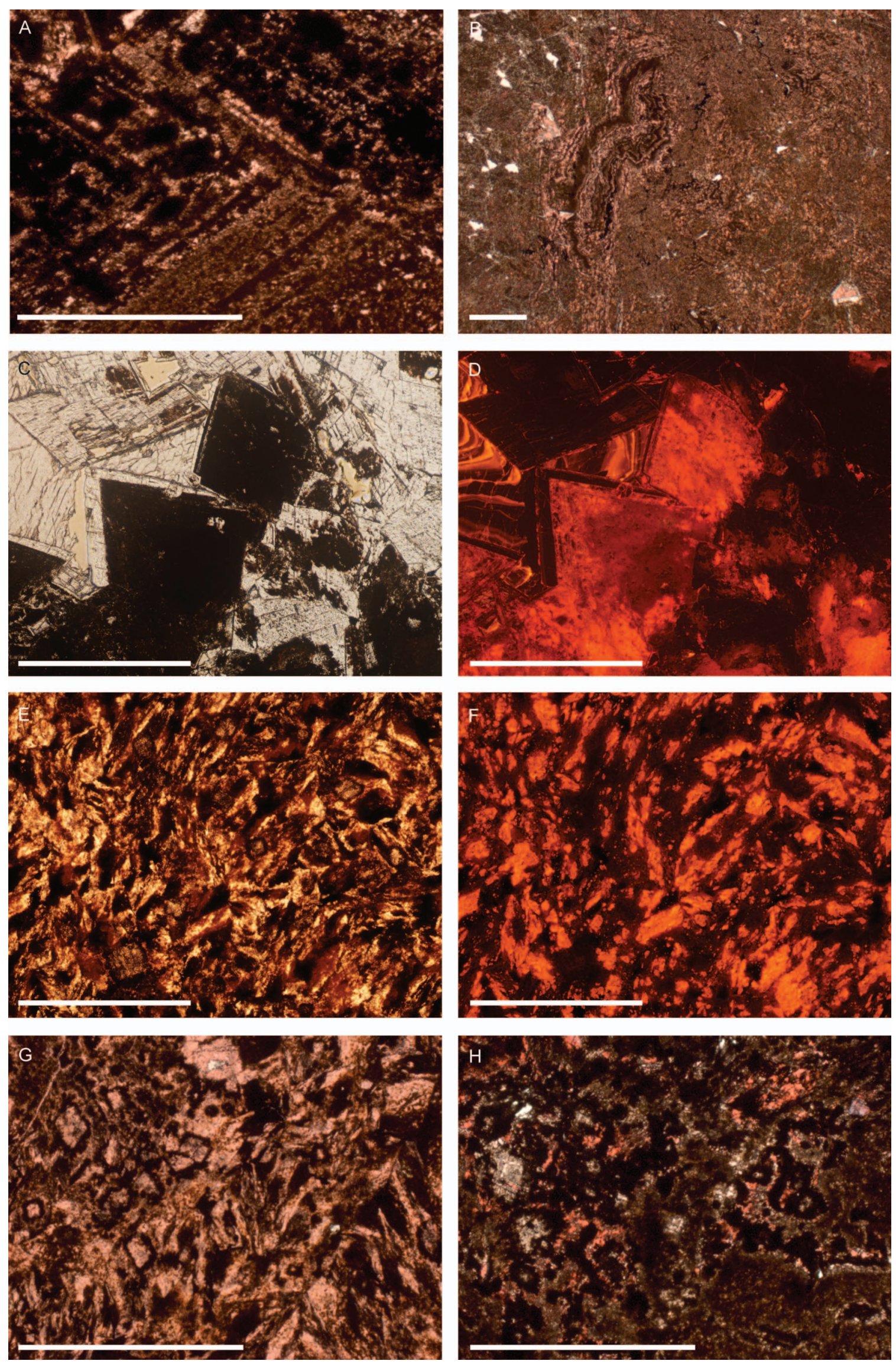
TABLE 1.-Major-element and minor-element data of bulk carbonate and separated dolomite fraction of the samples studied. The elemental concentrations of the fractions are expressed as for 100\% of dolomite or total carbonate, and the IR is the insoluble residue (noncarbonate) in the bulk rock. Also X-ray diffraction data are presented with dolomite percentage in total carbonate, dolomite stoichiometry (corrected for iron concentration, expressed in mol\%

$\mathrm{CaCO}_{3}$ ) and identification of noncarbonate minerals present in the bulk rock samples analyzed.

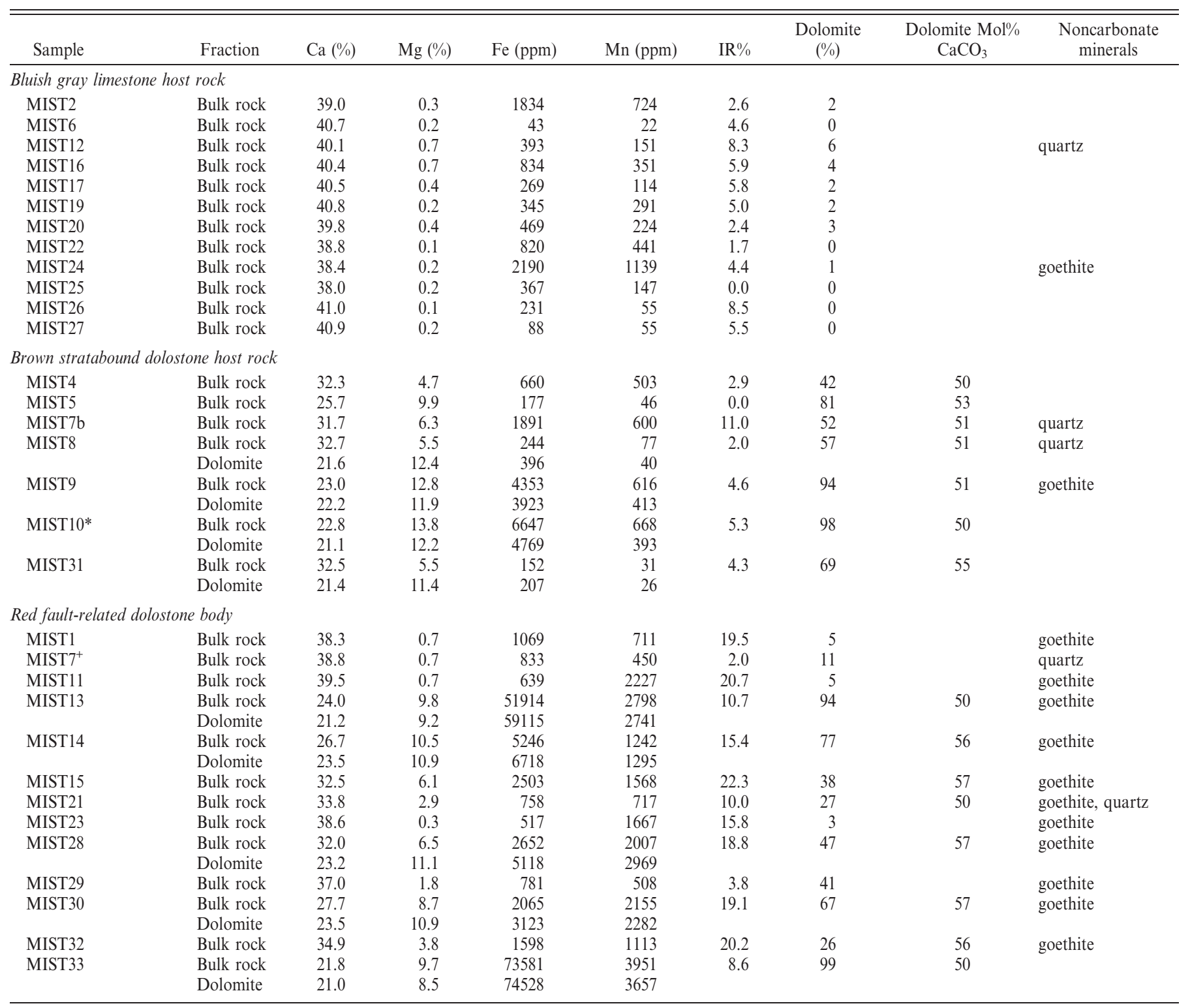

* MIST10 forms the contact between brown stratabound dolostone host rock and red fault-related dolostone and thus contains material of both.

${ }^{+}$MIST7 sample is host-rock dominated by large vein with red dolomite.

FIG. 10.-Microphotographs of alteration textures in FRD samples. Scale bar is $500 \mu \mathrm{m}$. A) Dark brown and lighter brown zonations in coarse D2 dolomite. B) Dark brown and lighter brown colloform bands. C) Unstained thin-section showing dark brown subhedral D2 dolomite crystals. D) Same view as in part C but under cathodoluminescence. The dark brown zones are dull to bright red luminescent, whereas the unaltered white dolomite zones and crystals are nonluminescent. The calcite covering the dolomite crystals displays a zoned luminescence pattern of alternating nonluminescent and bright orange luminescent zones. E) Fish-bone dedolomitization texture on unstained thin-section with small D1 dolomite rhomb relicts. F) Same view as part E but under cathodoluminescence. Small D1 dolomite rhombs are nonluminescent, and so are the dark brown mottles. In contrast, the lighter brown and calcite zones are bright reddish orange luminescent. G) Stained thin-section, showing a part in the hand sample where also the small D1 dolomite rhombs are calcitized. H) Example of mottled dark brown pattern in dedolomitized rock (stained thin-section). Small D1 dolomite rhomb relicts occur between the dark brown mottles and the more homogeneous lighter brown zone. 

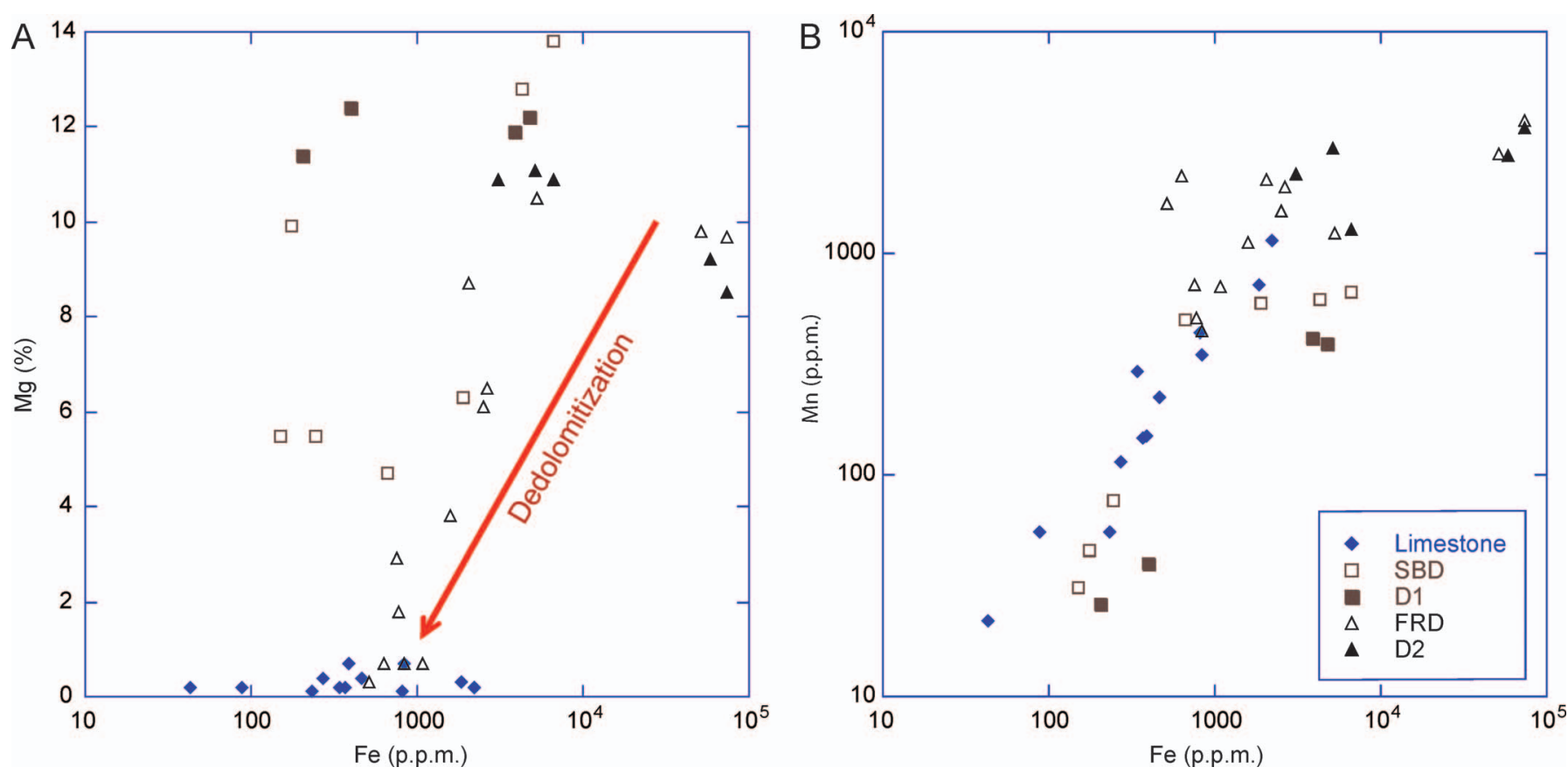

FIG. 11.-Crossplots of elemental concentrations for the bulk carbonate fraction of the bluish gray limestone, the brown stratabound dolomite (SBD) and red faultrelated dolomite (FRD) and the dolomite fraction of SBD (D1) and of FRD (D2). A) Fe versus Mg concentration, illustrating the lower Fe content in low Mg (altered) FRD compared to high Mg (unaltered) FRD samples, B) Fe versus Mn concentration. Note the positive correlation between the two variables.

the fluid; Kim and O’Neil 1997) and hydrocarbon escape (low $\delta^{13} \mathrm{C}$ associated with hydrocarbon; Peckmann and Thiel 2004). However, this alternative scenario is viewed as unlikely due to the absence of evidence for hydrocarbons (no hydrocarbon inclusions or evidence of tar at the

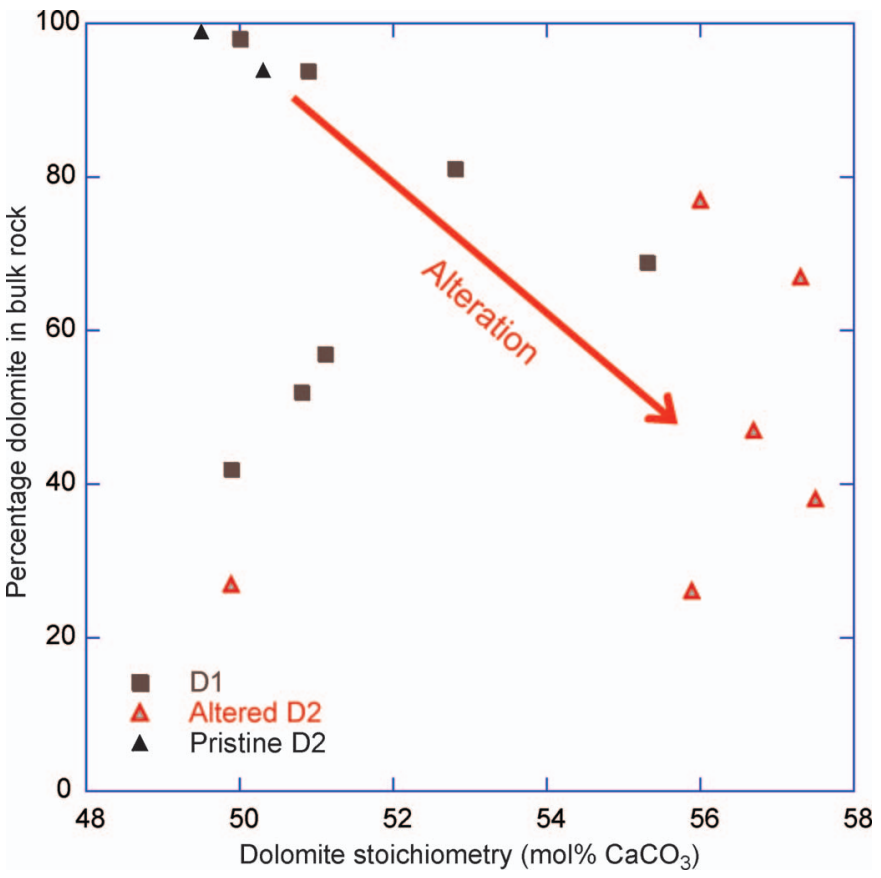

FIG. 12.-Dolomite content in bulk rock versus dolomite stoichiometry for dolomite within the SBD (D1) and the FRD (D2), both calculated from XRD analyses. The distinction is made between D2 that is well preserved with high content of dolomite in bulk rock and D2 that is affected by alteration and has lower percentages of dolomite in the bulk rock. Alteration of the dolomite samples is associated with an increase of $\mathrm{mol}^{2} \mathrm{CaCO}_{3}$ in the dolomite crystals. outcrop) and the position of the section (an outcrop exposed to meteoric waters and soil-derived $\mathrm{CO}_{2}$ ). Microbial activity could also influence the $\delta^{13} \mathrm{C}$ of pore waters (Coleman 1993; Whiticar 1999), but although it cannot be ruled out, no textures reminiscent of microbial precipitates (Lacelle et al. 2009) are present in the rocks.

The most likely hypothesis is thus that the low $\delta^{13} \mathrm{C}$ of the calcitized D2 implies near-surface conditions with a higher soil-derived carbon input and a high fluid/rock ratio (of about 1800 for a dedolomite $\delta^{13} \mathrm{C}$ of $-4.8 \%$ VPDB, a host-rock $\delta^{13} \mathrm{C}$ of $+1 \%$ VPDB and considering $\mathrm{C} 3$ vegetation in the soil cover; calculation based on Lohmann 1988, personal communication, $\delta^{13} \mathrm{C}_{\mathrm{i}}=\delta{ }^{13} \mathrm{C}_{\mathrm{HR}} \times \mathrm{F}_{\mathrm{c}}+\left(1-\mathrm{F}_{\mathrm{c}}\right) \times \delta{ }^{13} \mathrm{C}_{\mathrm{i}-1}$ with $\mathrm{F}_{\mathrm{c}}=$ mole fraction carbon in rock, using rock/water increment size of $\left.1 \times 10^{-6}\right)$. The high fluid/rock ratio needed in the context of exposure to (near-surface) meteoric water implies regular, moderate rainfall or wet conditions, and contrasts markedly with the current arid conditions prevailing in Oman. However, previous studies of cave deposits from northern Oman demonstrated that climatic conditions in the region switched multiple times between wetter conditions (increased Indian Ocean monsoons) and arid conditions over the course of the Pleistocene to Holocene (Burns et al. 2001). Burns et al. (2001) related the increased precipitation to orbital parameters, and suggested that wetter periods of 4 to 10 thousand years (ky) duration existed in Oman during maximum interglacial periods. Speleothem growth occurred mainly during the wetter periods, as also interpreted from zoned phreatic cave calcites from Jebel Madar in Oman showing monsoon-driven cyclicity (Immenhauser et al. 2007). The alternating wetter and drier periods are expected to drive changes in the oxygen and carbon isotope compositions of near-surface cements (Fig. 14). This link was demonstrated for $\delta^{18} \mathrm{O}$ in speleothems in Oman, with generally lower oxygen isotope values in speleothems formed during wetter periods compared to recent speleothems formed under arid climate conditions (Fleitmann et al. 2003). The absolute $\delta^{18} \mathrm{O}$ values between Fleitmann et al. (2003) and Immenhauser et al. (2007) are slightly different because of the mixing between surface waters and hydrothermal waters in the case study from Immenhauser et al. (2007). The difference in 


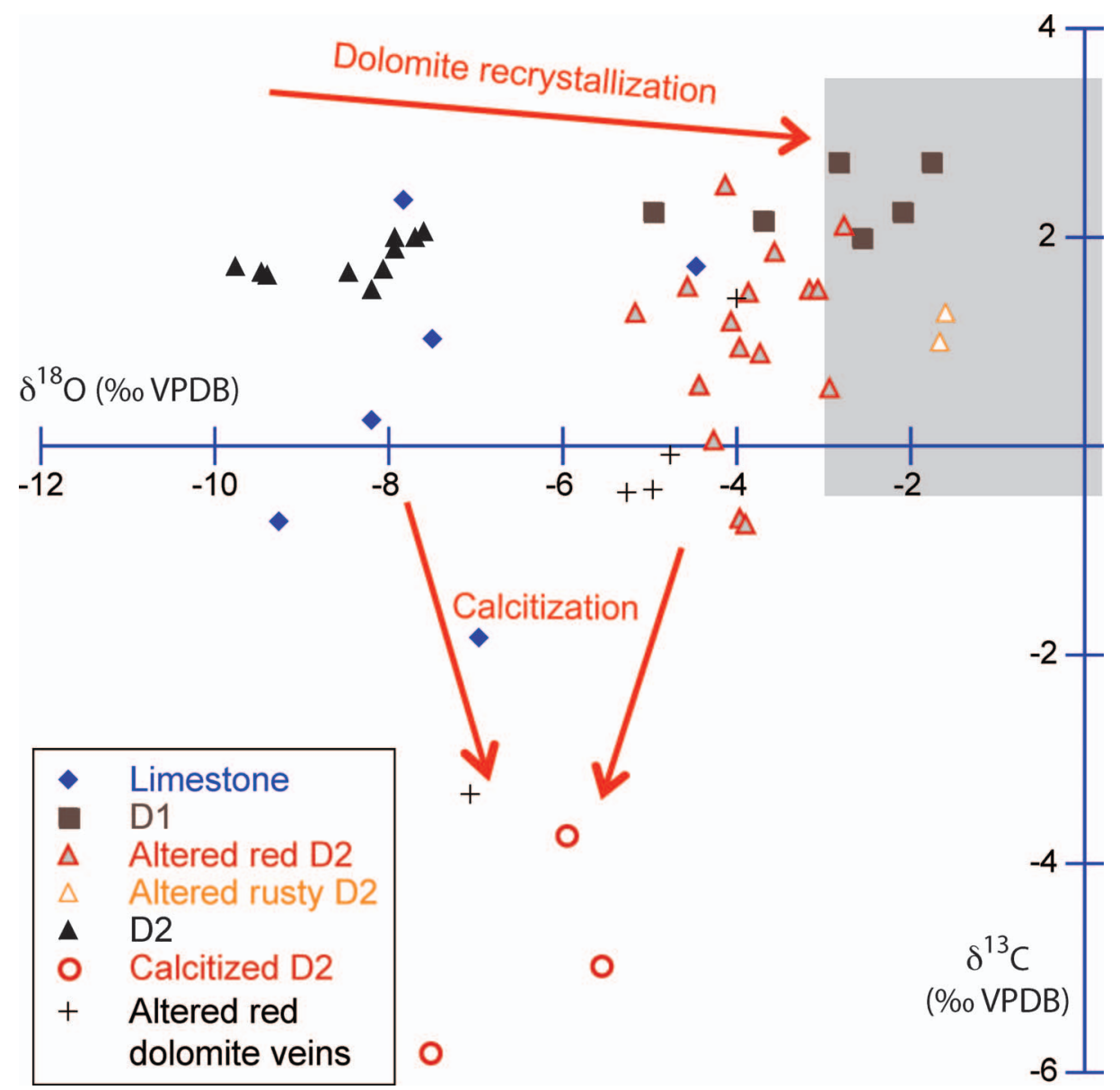

Fig. 13.-Carbon and oxygen isotope crossplot of the calcitic and dolomitic fractions. In the red fault-related dolomite (FRD) body, different degrees of altered dolomite were sampled, i.e., unaltered pristine $\mathrm{D} 2$, oxidized $\mathrm{D} 2$ dolomite (altered red D2 and altered rusty D2), and calcitized D2. Altered red dolomite occurring in veins is also shown. The dolomite alteration and calcitization follows a clear trend in isotopic signature. The gray box indicates the Jurassic marine calcite signature from Veizer et al. (1999). $\delta^{18} \mathrm{O}$ between more humid and more arid conditions is related to a difference in moisture source, i.e., a much greater percentage of the total moisture brought to the region originated in the Indian Ocean during the peak interglacial humid periods, whereas the northern Mediterranean moisture source was more important during arid periods (Fleitmann et al. 2003; see Fig. 14). Furthermore, increased rainfall results in a decrease of $\delta^{18} \mathrm{O}$ and $\delta \mathrm{D}$ of rainwater, even when the source of moisture remains constant (Lawrence and White 1991). A study by Whittaker et al. (2011) demonstrates an inverse relation between $\delta^{13} \mathrm{C}$ and amount of annual rainfall; a wetter climate will be linked to a lower $\delta^{13} \mathrm{C}$ recorded in nearsurface cements due to an open system with high soil moisture, and thus less plant stress, higher biological activity in the soil zone, and isotopic equilibrium between infiltrating fluid and soil $\mathrm{CO}_{2}$ (Harmon et al. 2004).

The data therefore suggest that the oxidation and calcitization of D2 occurred mainly during the wetter climatic periods of the Pleistocene to Holocene (Fig. 14A). The $\delta^{18} \mathrm{O}$ signature of the calcitized D2 (-7.5 to $-5.5 \%$ VPDB) are similar to those of Pleistocene to Holocene speleothems of the Hoti cave in northern Oman deposited during humid periods (Burns et al. 2001). However, the range of $\delta^{18} \mathrm{O}$ values for rainwater between arid and humid periods overlaps (Fig. 14; Fleitmann et al. 2003; Immenhauser et al. 2007), and therefore the main argument is that a large amount of rainfall is required to shift the $\delta^{13} \mathrm{C}$ to lower values. The $\delta^{13} \mathrm{C}$ values measured in the calcitized D2 $(-5.8$ to $-3.7 \%$ VPDB) fall at the lower end of the range of -6 to $-1 \%$ VPDB reported for the vadose speleothems in the Oman Hoti cave (Burns et al. 1998; Immenhauser et al. 2007). The goethite-calcite weathering fabric is thus interpreted as resulting from a high fluid/rock ratio (1800) between the host-rock and oxidative, meteoric fluids that had interacted with an extensive soil cover. The meteoric fluids must have had a high redox potential $\left(\mathrm{E}_{\mathrm{h}}\right)$ since ferroan dolomite is driven to goethite, and a high $\mathrm{Ca} /$ $\mathrm{Mg}$ ratio to promote dedolomitization (Fig. 14A).

The isotopic signature of altered, noncalcitized D2, resulting from the oxidation and dolomite recrystallization process, shows contrasting values. Pristine $\mathrm{D} 2$ is characterized by a strongly depleted $\delta^{18} \mathrm{O}$ signature (Fig. 13). The $\delta^{13} \mathrm{C}$ signature of the preserved D2 is similar to that of Jurassic carbonates (Veizer et al. 1999). The oxidation and recrystallization of $\mathrm{D} 2$ is accompanied by a shift towards less negative $\delta^{18} \mathrm{O}$ values (data from D2 to altered red and rusty D2; Fig. 13) whereas the original ${ }^{13} \mathrm{C}$ signature is retained. These results suggest that this goethiterecrystallized dolomite weathering fabric formed during the more arid climate periods (Fig. 14B) characterized by a lower amount of rainfall, a different prevalent moisture source leading to less depleted $\delta^{18} \mathrm{O}$ values (Fleitmann et al. 2003), and less soil development. The reduced soil development, a lower residence time of the fluid in the soil, and less interaction with soil-derived $\mathrm{CO}_{2}$ explain $\delta{ }^{13} \mathrm{C}$ values in the meteoric fluid that are less depleted during arid periods and can lead to a positive $\delta^{13} \mathrm{C}$ value in the dolomite (Fig. 14B). Furthermore, the lower amount of annual rainfall during the drier periods will lead to a depressed aquifer and a lower fluid/rock ratio. Using the equation of Lohmann (1988, personal communication), a fluid/rock ratio of 60 to 450 results in a cement with a $\delta^{18} \mathrm{O}$ reflecting the meteoric fluid composition (thus not host-rock buffered, and considering that temperature and fractionation factor, here for dolomite, determine the shift between the fluid $\delta^{18} \mathrm{O}$ and the recrystallized dolomite $\delta^{18} \mathrm{O}$ ) and a $\delta^{13} \mathrm{C}$ that is completely host-rock buffered (equation $\delta^{18} \mathrm{O}_{\mathrm{i}}=\delta^{18} \mathrm{O}_{\mathrm{HR}} \times \mathrm{F}_{\mathrm{o}}+\left(1-\mathrm{F}_{\mathrm{o}}\right) \times \delta^{18} \mathrm{O}_{\mathrm{j}-1}$ with $\mathrm{F}_{\mathrm{o}}=$ mole fraction oxygen in rock and $\delta^{18} \mathrm{O}_{\mathrm{j}}=\left(\delta^{18} \mathrm{O}_{\mathrm{i}}-1000 \times\right.$ 


\section{A: Humid climate}

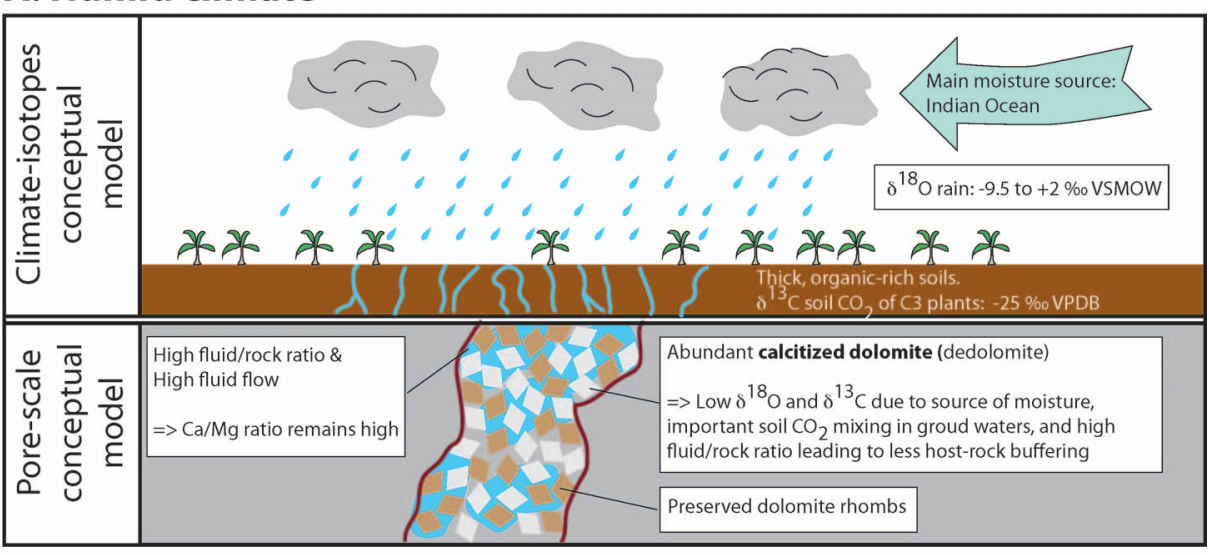

\section{B: Arid climate}

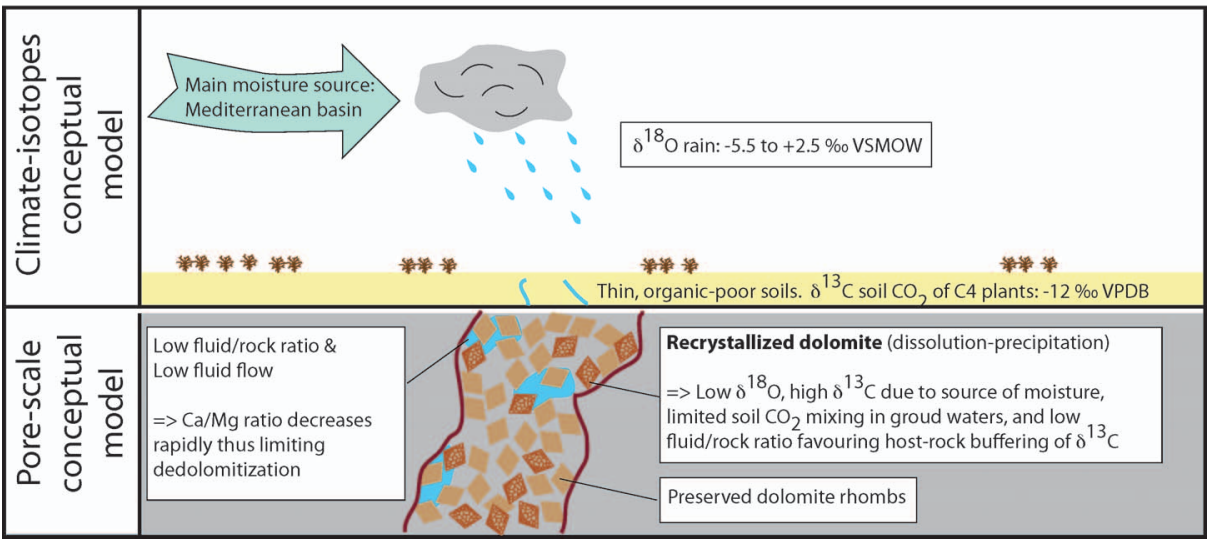

FIG. 14.- Schematic diagram of conceptual model for the relation between climate and the weathering fabrics, and their stable oxygen and carbon isotope composition. The oxygen isotope values for rain-water are based on Fleitmann et al. (2003). A) Humid climate during the peak interglacial periods, B) Arid climatic periods.
$\left.\mathrm{F}_{\mathrm{o}} \times(\alpha-1)\right) /\left(\mathrm{F}_{\mathrm{o}} \times(\alpha-1)+1\right)$, based on $\delta^{18} \mathrm{O}$ of fluid of $-5 \%$ VSMOW and $\delta^{18} \mathrm{O}$ of host-rock of $-1 \%$ VPDB; equation for carbon as shown above and considering $\mathrm{C} 4$ vegetation in the soil cover; increment size of 0.1). The fact that the wet versus arid periods involve meteoric fluids with different characteristics and that the lower amount of rainfall translate into lower fluid-rock interaction can help explaining the different fabric, i.e., calcitization versus recrystallization of dolomite (compare Fig. 14A and B). Recrystallization here is defined as a dissolution-reprecipitation process in diagenetic studies (Machel 1997). An important question related to this interpretation is how dolomite can recrystallize at near-surface conditions, since dolomite dissolutionreprecipitation at low temperature may be inhibited kinetically. Dolomite precipitation at ambient temperatures is a challenging problem because dolomite is rarely found in recent sedimentary environments at surface temperatures (Machel 2004). However, several studies present lowtemperature dolomitization, such as island dolomite cases (Budd 1997) or Ca-rich dolomite that formed from a huntite precursor (Alonso-Zarza and Martín-Pérez 2008). The oxidation and dolomite recrystallization process is texture-preserving, and this process is akin to a pseudomorphic replacement process where the initial phase is a metastable ferroan dolomite and the replacement phase is a more stable, iron-poor dolomite. This process could be classified as an interface-coupled dissolutionreprecipitation process (Putnis and Putnis 2007).

For dolomite recrystallization to occur, the diagenetic fluid must have had a high redox potential $\left(\mathrm{E}_{\mathrm{h}}\right)$ and a $\mathrm{Ca} / \mathrm{Mg}$ ratio within the stability field of dolomite (as to prevent calcitization). A low $\mathrm{Ca} / \mathrm{Mg}$ ratio is consistent with the model of humid versus arid climate periods and can be explained even if the source of the fluid (i.e., meteoric fluids) remains the same between the two climate modes (Fig. 14). A high fluid flow and a high fluid/rock ratio are needed to keep the $\mathrm{Ca} / \mathrm{Mg}$ ratio in the pore space high enough to calcitize dolomite: when $\mathrm{Mg}$ is brought into solution during dolomite dissolution it drives the $\mathrm{Ca} / \mathrm{Mg}$ ratio of the meteoric fluid towards lower values, and if a constant influx of new dedolomitizing fluid is not available the process of dedolomitization ceases. In the proposed model, during arid periods the low fluid/rock ratio would favor a low $\mathrm{Ca} / \mathrm{Mg}$ ratio, limited dissolution of the dolomite, and more extensive recrystallization.

In summary, the oxidation and recrystallization of dolomite by moderate interaction with meteoric fluids is interpreted to have caused a shift towards less negative $\delta^{18} \mathrm{O}$ and probably happened during one or more arid periods in the course of the Pleistocene to Recent, when surface runoff was more limited (Burns et al. 2001). Some of the (probably already partially oxidized and recrystallized) D2 could be calcitized (partially) by meteoric fluids with a slightly more negative $\delta^{18} \mathrm{O}$ and a negative $\delta^{13} \mathrm{C}$ during a subsequent humid climatic phase (Fig. 14). The current arid conditions in Oman would be more favorable to texturepreserving dolomite recrystallization rather than calcitization. Thus, the main impact of climate over dedolomitization is to control the amount of meteoric fluids and soil development, resulting in differential mineralization pathways and $\delta^{13} \mathrm{C}$ values.

\section{Duration of Dedolomitization Events and Flow Focusing along Fractures}

Assuming that this conceptual model is correct, and that calcitization took place by high meteoric fluid-rock interaction (consistent with findings of De Groot 1967) during humid climate spells, the time 
required to complete the process of calcitization can be contrasted with the total duration of one or multiple episodes of humid climate (estimated between 4 to $10 \mathrm{ky}$ for a single humid period; Burns et al. 2001). The time required for calcitization can be estimated by a simplified calculation assuming a dolomite dissolution rate of $1.7 \times 10^{-4} \mathrm{mmol} / \mathrm{kg}$ of $\mathrm{H}_{2} \mathrm{O} / \mathrm{yr}$ (Back et al. 1993; Deike 1990) and an annual rainfall of $2000 \mathrm{~mm}$ (average current tropical monsoon climate): the result is that $450 \mathrm{ky}$ would be needed to dedolomitize only a $1-\mathrm{cm}$ thick layer of dolomite. The duration of $450 \mathrm{ky}$ is one order of magnitude higher than the total duration of multiple humid periods in the Pleistocene-Holocene (Burns et al. 2001), and the dedolomitization process penetrated the rock to at least $50 \mathrm{~cm}$.

One possibility to explain the discrepancy between the duration of humid periods and the time required to dedolomitize the rocks is that the dolomite dissolution rate used in the calculation could have been underestimated: dissolution rates depend on the stability of the dolomite, and the latter relates to the specific geochemical characteristics of the mineral. However, even using the high end of the range of modern rates of dolomite dissolution $\left(4.3 \times 10^{-4} \mathrm{mmol} / \mathrm{kg}\right.$ of $\mathrm{H}_{2} \mathrm{O} / \mathrm{yr}$; Deike 1990) yields an estimate of $170 \mathrm{ky}$ to dedolomitize a 1-cm-thick layer of dolomite with $2000 \mathrm{~mm}$ rainfall per year. A more likely explanation for the discrepancy in dedolomitization rates is that taking only the annual rainfall into consideration results in an underestimated fluid flow because groundwater and surface fluid flow focusing are not considered. Deike (1990) has highlighted the importance of the mass of water transported in an aquifer, and has demonstrated that in the case study a significant portion of the rock could be dedolomitized within $10 \mathrm{ky}$ (Deike 1990). Although the current study did not investigate quantitative aspects of flow focusing, factors controlling fluid migration (such as topography and fracture network) must play a key role in dedolomitization at Wadi Mistal: the FRD occurs along a fault and associated fracture network, which is hypothesized to have acted as a preferential conduit for meteoric fluids. This dynamic process of preferential fluid pathways along fractures would result in larger volumes of meteoric water flowing along the dolomite body, and would decrease the time needed to dedolomitize D2 within the FRD. Future work on dedolomitization should focus on a more quantitative reconstruction of flow focusing along fractures.

\section{New Insights from Dolomite Stoichiometry}

Dolomite stoichiometry influences susceptibility to dedolomitization, since an excess of $\mathrm{Ca}$ causes instability in the dolomite lattice structure (Zeidan and Basyuni 1998; Nader et al. 2008). This relation was not evident in this study, where pristine D2 dolomite is nearly stoichiometric, whereas weathered and pristine D1 dolomite samples are also nearly stoichiometric or have a small excess of $\mathrm{Ca}$. Interestingly, it is found that weathered, recrystallized D2 is non-stoichiometric with high Ca excess (similar to the 56 to $57 \mathrm{~mol}_{\%} \mathrm{CaCO}_{3}$ reported in Frank 1981). Hence, in these strata, the $\mathrm{Ca}$ excess is not related to the original signature of the dolomite, but seems to result from the texture-preserving recrystallization and oxidation process with the formation of iron hydroxides during weathering. It is proposed that during the oxidation process, $\mathrm{Fe}^{2+}$ from the ferroan dolomite is oxidized to $\mathrm{Fe}^{3+}$ and forms goethite, while $\mathrm{Ca}^{2+}$ and $\mathrm{Mg}^{2+}$ from the ferroan dolomite are incorporated in the recrystallized dolomite. Because it is interpreted that fluid flow in the oxidation and dolomite recrystallization process (leading to goethite-dolomite fabric) is more limited than in the oxidation and calcitization process (resulting in goethite-calcite fabric), the $\mathrm{Ca}$ and $\mathrm{Mg}$ ions are probably locally derived. Since the $\mathrm{Fe}^{2+}$ (which takes the $\mathrm{Mg}$ sites in the dolomite lattice) is lost due to oxidation, the resulting relative ratio of $\mathrm{Ca} / \mathrm{Mg}$ is higher than in the pristine ferroan dolomite, which explains the measured excess in $\mathrm{Ca}$ in the weathered dolomite.

\section{SUMMARY AND CONCLUSIONS}

This study highlights that:

1. Weathering of dolomite leads to a range of textures that identify one or more dedolomitization and recrystallization events that record the diagenetic history of the rocks.

2. Different types of dolomite respond variably to changing physicochemical conditions. A main subaerial dedolomitization phase was identified that took place in the Pleistocene-Holocene and that affected the iron-rich D2 dolomite more than the D1 dolomite. In the case of the FRD of north Oman, iron concentration in dolomite seems to have played a role in its susceptibility to subaerial weathering. In addition, petrographic evidence suggests the occurrence of an earlier, shallow-burial dedolomitization phase that affected only the D1 dolomite and predates D2.

3. The stoichiometry of pristine D1 and D2 dolomite (corrected for iron concentration) is comparable. However, the weathered D2 dolomite is non-stoichiometric ( 56 to $57 \mathrm{~mol}^{\%} \mathrm{CaCO}_{3}$ ). This nonstoichiometry is attributed to the oxidation of iron from the ferroan dolomite and dolomite recrystallization with higher $\mathrm{Ca} / \mathrm{Mg}$ ratio.

4. Stable oxygen isotope values of pristine and altered D2 dolomite demonstrate an isotopic resetting of the dolomite signature during oxidation and recrystallization of the ferroan D2 dolomite. This oxygen isotope shift towards less negative values and the lack of change in the carbon isotope composition between pristine and altered D2 dolomite can be explained by dolomite recrystallization during oxidation due to the interaction with low-temperature meteoric fluids depleted in soil-derived $\mathrm{CO}_{2}$ or low fluid-rock interaction and thus host-rock buffering, in contrast to the isotopic signature of calcitized D2.

5. Pleistocene to Holocene surface weathering took place in two different modes, leading to two different alteration textures. In one case, dolomite was affected by oxidation and dolomite recrystallization, resulting in a goethite-recrystallized dolomite fabric. In the other case, dolomite was oxidized and calcitized, causing a goethitededolomite fabric. The stable isotope results and comparison with previous studies on stable isotopes in Oman speleothems and Pleistocene to Holocene climate interpretations suggest that the weathering textures can be linked to the climatic conditions. Oxidation and calcitization occurred during the wet periods, by meteoric fluids that contained soil-derived carbon, thus shifting the $\delta^{13} \mathrm{C}$ of the dolomite to more negative values. Oxidation and dolomite recrystallization happened in the more arid periods, with less soil development and less fluid/rock interaction.

\section{ACKNOWLEDGMENTS}

This research project is part of the Qatar Carbonates and Carbon Storage Research Center (QCCSRC), funded by Qatar Petroleum, the Qatar Science and Technology Panel (QSTP), and Shell International. Michael Poppelreiter, Conxita Taberner, and Andrew Berry are thanked for fruitful discussions and excellent scientific advice. We would like to thank Martin Gill for running the X-ray diffraction analyses. We acknowledge Catherine Unsworth for assistance with ICP-AES chemical analyses and Anton Kearsley for assistance with operating the SEM. We thank Sarah Hayes for the preparation of some samples for ICP-AES analyses. We acknowledge editor Eugene Rankey and reviewers Sarah Carmichael, Mitch Malone, and associate editor Leslie Melim for their constructive comments, which helped improve this paper.

\section{REFERENCES}

Al-Hashimi, W.S., and Hemingway, J.E., 1973, Recent dedolomitization and the origin of the rusty crusts of Northumberland: Journal of Sedimentary Petrology, v. 43, p. 82-91. 
Alonso-Zarza, A.M., and Martín-Pérez, A., 2008, Dolomite in caves: Recent dolomite formation in oxic, non-sulfate environments. Castañar Cave, Spain Sedimentary Geology, v. 205, p. 160-164.

Ayora, C., Taberner, C., Saaltink, M.W., and Carrera, J., 1998, The genesis of dedolomites: a discussion based on reactive transport modeling: Journal of Hydrology, v. 209, p. 346-365.

Back, W., Hanshaw, B.B., Plummer, L.N., Rahn, P.H., Rightmire, C.T., and Rubin, M., 1983, Process and rate of dedolomitization: mass transfer and ${ }^{14} \mathrm{C}$ dating in a regional carbonate aquifer: Geological Society of America, Bulletin, v. 94, p $1415-1429$.

Béchennec, F., Le Métour, J., Rabu, D., Villey, M., and Beurrier, M., 1988, The Hawasina Basin: A fragment of a starved passive continental margin, thrust over the Arabian Platform during obduction of the Sumail Nappe: Tectonophysics, v. 151, p. 323-343.

Bischoff, J.L., Juliá, R., Shanks, W.C, III, and Rosenbauer, R.J., 1994, Karstification without carbonic acid: bedrock dissolution by gypsum-driven dedolomitization: Geology, v. 22, p. 995-998.

Braun, M., and Friedman, G.M., 1970, Dedolomitization fabric in peels: a possible clue to unconformity surfaces: Journal of Sedimentary Petrology, v. 40, p. 417-419.

Budai, J.M., Lohmann, K.C., and Owen, R.M., 1984, Burial dedolomite in the Mississippian Madison limestone, Wyoming and Utah thrust belt: Journal of Sedimentary Petrology, v. 54, p. 276-288.

BudD, D.A., 1997, Cenozoic dolomites of carbonate islands: their attributes and origin: Earth-Science Reviews, v. 42, p. 1-47.

Burns, S.J., Matter, A., Frank, N., and Mangini, A., 1998, Speleothem-based paleoclimate record from northern Oman: Geology, v. 26, p. 499-502.

Burns, S.J., Fleitmann, D., Matter, A., Neff, U., And Mangini, A., 2001, Speleothem evidence from Oman for continental pluvial events during interglacial periods: Geology, v. 29, p. 623-626.

Cantrell, D.L., Al-Khammash, A., and Jenden, P.D., 2007, Characterization and significance of dedolomite in Wadi Nisah, central Saudi Arabia: GeoArabia, v. 12, p $15-30$.

Coleman, M.L., 1993, Microbial processes: controls on the shape and composition of carbonate concretions: Marine Geology, v. 113, p. 127-140.

De Groot, K., 1967, Experimental dedolomitization: Journal of Sedimentary Petrology, v. 37 , p. $1216-1220$.

DeIKE, R.G., 1990, Dolomite dissolution rates and possible Holocene dedolomitization of water-bearing units in the Edwards aquifer, South-Central Texas: Journal of Hydrology, v. 112, p. 335-373.

Dickson, J.A.D., 1966, Carbonate identification and genesis as revealed by staining: Journal of Sedimentary Petrology, v. 36, p. 491-505.

Evamy, B.D., 1963, The application of chemical staining technique to a study of dedolomitization: Sedimentology, v. 2, p. 164-170

Evamy, B.D., 1967, Dedolomitization and the development of rhombohedral pore in limestones: Journal of Sedimentary Petrology, v. 37, p. 1204-1215.

Fleitmann, D., Burns, S.J., Neff, U., Mangini, A., And Matter, A., 2003, Changing moisture sources over the last 330,000 years in Northern Oman from fluid-inclusion evidence in speleothems: Quaternary Research, v. 60, p. 223-232.

Folkman, Y., 1969, Diagenetic dedolomitization in the Albian-Cenomanian Yagur dolomite on Mount Carmel (northern Israel): Journal of Sedimentary Petrology, v. 39, p. $380-385$.

Frank, J.R., 1981, Dedolomitization in the Taum Sauk limestone (Upper Cambrian), Southeast Missouri: Journal of Sedimentary Petrology, v. 51, p. 7-18

Genty, D., Blamart, D., Ghaleb, B., Plagnes, V., Causse, C., Bakalowicz, M., Zouari, K., Chkir, N., Hellstrom, J., Wainer, K., and Bourges, F., 2006, Timing and dynamics of the last deglaciation from European and North African $\delta^{13} \mathrm{C}$ stalagmite profiles - comparison with Chinese and South Hemisphere stalagmites: Quaternary Science Reviews, v. 25, p. 2118-2142.

Goldberg, M., 1967, Supratidal dolomitization and dedolomitization in Jurassic rocks of Hamakhtesh Haqatan, Israel: Journal of Sedimentary Petrology, v. 37, p. 760-773.

Grosz, S., Matthews, A., Ilani, S., Ayalon, A., and Garfunkel, Z., 2006, Iron mineralization and dolomitization in the Paran Fault zone, Israel: implications for low-temperature basinal fluid processes near the Dead Sea Transform: Geofluids, v. 6 , p. $137-153$.

Hanna, S.S., 1990, The Alpine deformation of the Central Oman Mountains, in Robertson, A.H.F., Searle, M.P., and Ries, A.C., eds., The Geology and Tectonics of the Oman Region: Geological Society of London, Special Publication 49, p. 341-359.

Harmon, R.S., Schwarz, H.P., Gascoyne, M., Hess, J.W., and Ford, D.C., 2004 Paleoclimate information from speleothems: the present as a guide to the past, in Sasowsky, I.D., and Mylroie, J., eds., Studies of Cave Sediments: Physical and Chemical Records of Paleoclimate: New York, Kluwer Academic Publishers, p. 199-226.

Hilgers, C., Kirschner, D.L., Breton, J.-P., And Urai, J.L., 2006, Fracture sealing and fluid overpressures in limestones of the Jabal Akhdar dome, Oman Mountains: Geofluids, v. 6, p. 168-184.

Hillgärtner, H., Van Buchem, F.S.P., Gaumet, F., Razin, P., Pittet, B., Grötsch, J., And Droste, H., 2003, The Barremian-Aptian evolution of the Eastern Arabian carbonate platform margin (Northern Oman): Journal of Sedimentary Research, v. 73, p. $756-773$.

Immenhauser, A., Dublyansky, Y.V., Verwer, K., Fleitman, D., and Pashenko, S., 2007, Textural, elemental, and isotopic characteristics of Pleistocene phreatic cave deposits (Jabal Madar, Oman): Journal of Sedimentary Research, v. 77, p. 68-88.
James, N.P., Bone, Y., And Kyser, T.K., 1993, Shallow burial dolomitization and dedolomitization of mid-Cenozoic, cool-water, calcitic, deep-shelf limestones, Southern Australia: Journal of Sedimentary Petrology, v. 63, p. 528-538.

Jones, B., Pleydell, S.M., Kwoi-Choi, N., And Longstaffe, F.J., 1989, Formation of poikilotopic calcite-dolomite fabrics in the Oligocene-Miocene Bluff formation of Grand Cayman, British West Indies: Bulletin of Canadian Petroleum Geology, v. 37, p. $255-265$.

KATZ, A., 1971, Zoned dolomite crystals: Journal of Geology, v. 79, p. 38-51

Kenny, R., 1992, Origin of disconformity dedolomite in the Martin Formation (Late Devonian, northern Arizona): Sedimentary Geology, v. 78, p. 137-146.

Khalaf, F.I., and Abdal, M.S., 1993, Dedolomitization of dolocrete deposits in Kuwait, Arabian Gulf: Geologische Rundschau, v. 82, p. 741-749.

KIM, S.-T., AND O'NEIL, J.R., 1997, Equilibrium and nonequilibrium oxygen isotope effects in synthetic carbonates: Geochimica et Cosmochimica Acta, v. 61, p 3461-3475.

Lacelle, D., Pellerin, A., Clark, I.D., Lauriol, B., and Fortin, D., 2009 (Micro)morphological, inorganic-organic isotope geochemistry and microbial populations in endostromatolites (cf. fissure calcretes), Haughton impact structure, Devon Island, Canada: The influence of geochemical pathways on the preservation of isotope biomarkers: Earth and Planetary Science Letters, v. 281, p. 202-214.

Lawrence, J.R., And White, J.W.C., 1991, The elusive climate signal in the isotopic composition of precipitation: Geochemical Society, Special Publications, v. 3, p $169-185$.

Le Métour, J., Platel, J.P., Béchennec, F., Berthiaux, A., Chevrel, S., Dubreuilh, J., Roger, J., And Wyns, R., 1993, Geological map of Oman, scale 1:1,000,000: Directorate General of Minerals, Oman Ministry of Petroleum and Minerals.

Lohmann, K.C., 1988, Geochemical patterns of meteoric diagenetic systems and their application to studies in paleokarst, in James, N.P., and Choquette, P.W., eds., Paleokarst: New York, Springer-Verlag, p. 58-80.

Lumsden, D.N., 1979, Discrepancy between thin section and X-ray estimates of dolomite in limestones: Journal of Sedimentary Petrology, v. 49, p. 429-436.

Machel, H.G., 1997, Recrystallization versus neomorphism, and the concept of "significant recrystallization" in dolomite research: Sedimentary Geology, v. 113, p. $161-168$

MACHEL, H.G., 2004, Concepts and models of dolomitization: a critical reappraisal, in Braithwaite, C.J.R., Rizzi, G., and Darke, G., eds., The Geometry and Petrogenesis of Dolomite Hydrocarbon Reservoirs: Geological Society of London, Special Publication 235 , p. 7-63.

Magaritz, M., AND Kafri, U., 1981, Stable isotope and $\mathrm{Sr}^{2+} / \mathrm{Ca}^{2+}$ evidence of diagenetic dedolomitization in a schizohaline environment: Cenomanian of northern Israel: Sedimentary Geology, v. 28, p. 29-41.

Mann, A., Hanna, S.S., and Nolan, S.C., 1990, The post-Campanian tectonic evolution of the Central Oman Mountains: Tertiary extension of the Eastern Arabian Margin, in Robertson, A.H.F., Searle, M.P., and Ries, A.C., eds., The Geology and Tectonics of the Oman Region: Geological Society of London, Special Publication 49, p. $549-563$.

Masse, J.-P., Borgomano, J., and Al Maskiry, S., 1997, Stratigraphy and tectonosedimentary evolution of a late Aptian-Albian carbonate margin: the northeastern Jebel Akhdar (Sultanate of Oman): Sedimentary Geology, v. 113, p 269-280.

Masse, J.-P., Borgomano, J., And Al MaskiRy, S., 1998, A platform-to-basin transition for lower Aptian carbonates (Shuaiba Formation) of the northeastern Jebel Akhdar (Sultanate of Oman): Sedimentary Geology, v. 119, p. 297-309.

Nader, F.H., Swennen, R., and Keppens, E., 2008, Calcitization/dedolomitization of Jurassic dolostones (Lebanon): results from petrographic and sequential geochemical analyses: Sedimentology, v. 55, p. 1467-1485

Peckmann, J., And Thiel, V., 2004, Carbon cycling at ancient methane-seeps: Chemical Geology, v. 205, p. 443-467.

Poupeau, G., Saddiei, O., Michard, A., Goffé, B., and Oberhänsli, R., 1998, Late thermal evolution of the Oman Mountains subophiolithic windows: apatite fissiontrack thermochronology: Geology, v. 26, p. 1139-1142.

Pratt, B.R., And Smewing, J.D., 1993, Early Cretaceous platform-margin configuration and evolution in the Central Oman Mountains, Arabian Peninsula: American Association of Petroleum Geologists, Bulletin, v. 77, p. 225-244.

Putnis, A., AND Putnis, C.V., 2007, The mechanism of reequilibration of solids in the presence of a fluid phase: Journal of Solid State Chemistry, v. 180, p. 1783-1786.

Rabu, D., Le Métour, J., Béchennec, F., Beurrier, M., Villey, M., and BourdillonJeudy DE GRISSAC, C., 1990, Sedimentary aspects of the Eo-Alpine cycle on the northeast edge of the Arabian Platform (Oman Mountains), in Robertson, A.H.F. Searle, M.P., and Ries, A.C., eds., The Geology and Tectonics of the Oman Region: Geological Society of London, Special Publication 49, p. 49-68.

Robertson, A.H.F., 1987, Upper Cretaceous Muti Formation-transition of a Mesozoic carbonate platform to a foreland basin in the Oman Mountains: Sedimentology, v. 34, p. 1123-1142.

Rosenbaum, J., and Sheppard, S.M., 1986, An isotopic study of siderites, dolomites and ankerites at high temperatures: Geochimica et Cosmochimica Acta, v. 54, p. 603-610. Saddiei, O., Michard, A., Goffé, B., Poupeau, G., and Oberhänsli, R., 2006, Fissiontrack thermochronology of the Oman Mountains continental windows, and current problems of tectonic interpretation: Société Géologique de France, Bulletin, v. 177, p. 127-134.

Sanz-Rubio, E., Sánchez-Moral, S., Cañaveras, J.C., Calvo, J.P., and Rouchy, J.M. 2001, Calcitization of $\mathrm{Mg}-\mathrm{Ca}$ carbonate and $\mathrm{Ca}$ sulphate deposits in a continenta Tertiary basin (Calatayud Basin, NE Spain): Sedimentary Geology, v. 140, p. 123-142. 
Searle, M.P., and Graham, G.M., 1982, "Oman Exotics"-Oceanic carbonate buildups associated with the early stages of continental rifting: Geology, v. 10, p. 43-49.

Sharp, I., Gillespie, P., Morsalnezhad, D., Taberner, C., Karpuz, R., Vergés, J., Horbury, A., Pickard, N., Garland, J., and Hunt, R., 2010, Stratigraphic architecture and fracture-controlled dolomitization of the Cretaceous Khami and Bangestan groups: an outcrop case study, Zagros Mountains, Iran, in Van Buchem,

F.S.P., Gerdes, K.D., and Esteban, M., eds., Mesozoic and Cenozoic Carbonate Systems of the Mediterranean and the Middle East: Stratigraphic and Diagenetic Reference Models: Geological Society of London, Special Publication 329, p. 343-396. Shearman, D.J., Khouri, J., and Taha, S., 1961, On the replacement of dolomite by calcite in some Mesozoic limestones from the French Jura: Proceedings of the Geologists' Association, v. 71, p. 1-12.

Veizer, J., Ala, D., Azmy, K., Bruckschen, P., Buhl, D., Bruhn, F., Carden, G.A.F., Diener, A., Ebneth, S., Godderis, Y., Jasper, T., Korte, C., Pawellek, F., Podlaha, O.G., and Strauss, H., $1999,{ }^{87} \mathrm{Sr} /{ }^{86} \mathrm{Sr}, \delta^{13} \mathrm{C}$ and $\delta^{18} \mathrm{O}$ evolution of Phanerozoic seawater: Chemical Geology, v. 161, p. 59-88
Von Morlot, A., 1847, Veber Dolomit und seine Kunstliche Darstelling aus Kalkstein: Naturwissenschaftliche Abhandlungen, gesammelt und durch Subscription lursg: Von Wilhelm Haidinger, v. 1, p. 305-315.

Whiticar, M.J., 1999, Carbon and hydrogen isotope systematics of bacterial formation and oxidation of methane: Chemical Geology, v. 161, p. 291-314.

Whittaker, T.E., Hendy, C.H., and Hellstrom, J.C., 2011, Abrupt millennial-scale changes in intensity of Southern Hemisphere westerly winds during marine isotope stages 2-4: Geology, v. 39, p. 455-458.

YAPP, C., 2001, Rusty relics of Earth history: Iron (III) oxides, isotopes and surficial environments: Annual Review of Earth and Planetary Sciences, v. 29, p. 165-199.

Zeidan, R.H., and Basyuni, M.H., 1998, Modes of occurrence of dolomite in some Arabian carbonate rocks: Journal of King Abdulaziz University, Earth Sciences, v. 10, p. 1-16.

Received 29 March 2011; accepted 28 October 2011. 